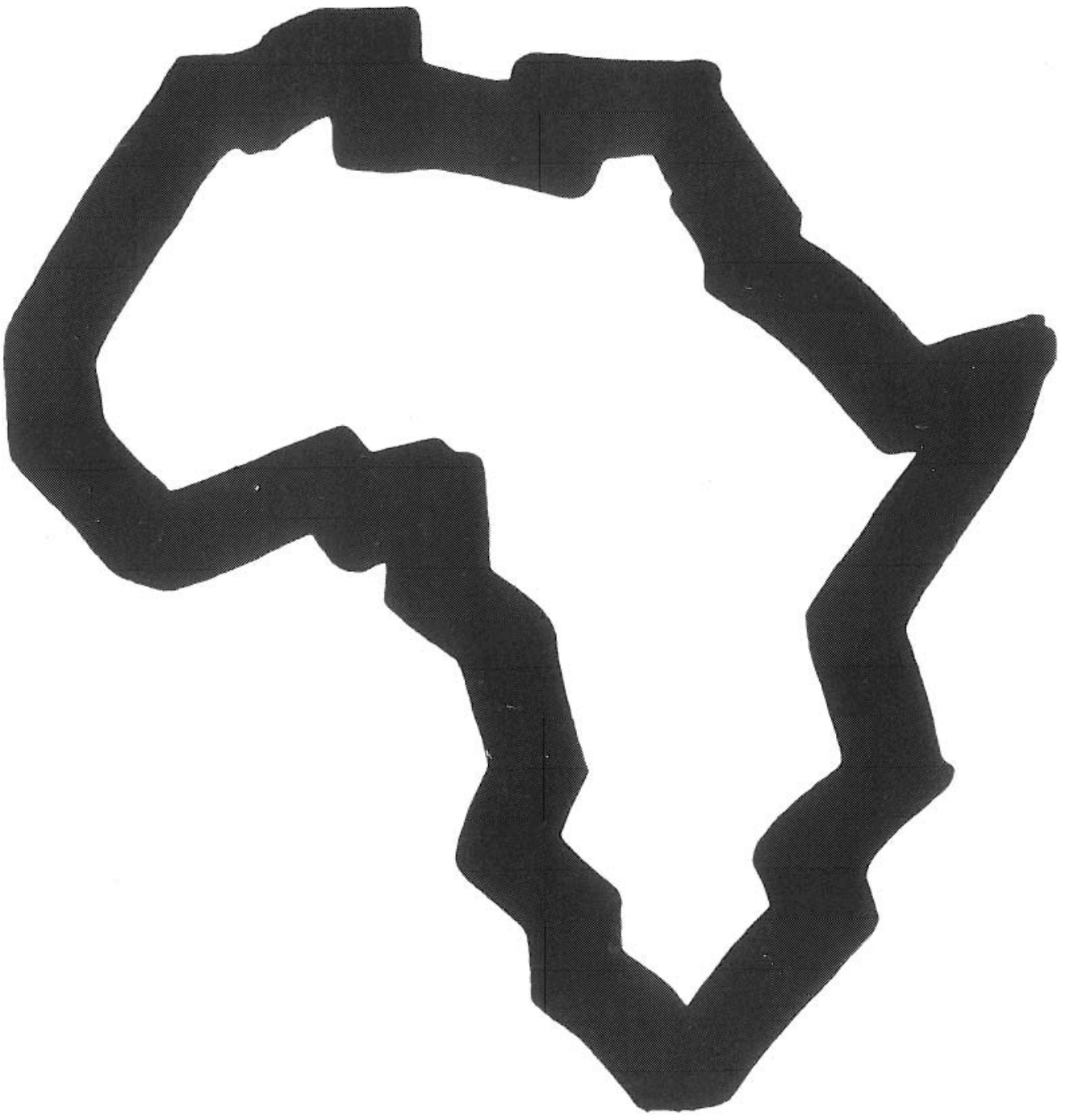

\title{
Ujamaa Villages in Tanzania: A Bibliography
}

by

Dean E. McHenry, Jr. 
UJPMAA VILLAGES IN TANZANIA:

A BIBLIOGRAPHY 
UJAMAA VILLAGES IN TANZANIA:

A BIBLIOGRAPHY

by

Dean E. McHenry, Jr.

Brown University

Scandinavian Institute of African Studies, Uppsala 1981 
The most ambitious effort of any African country to initiate the establishment of a socialist society is Tanzania's attempt to create ujamaa villages. This is a bibliography of books, articles and papers on the subject published up to 1980. Most of the materials are in English, several are in Swahili, some in French, a few in German and still fewer in other languages. The works are organized by their dominant theme into sections within four basic subject categories: the evolution, formation, character and evaluation of ujamaa villages or efforts to build ujamaa villages. An author and a subject index are included to facilitate further the location of relevant studies.

\section{ABBREVIATIONS}

BRALUP Bureau of Resource Assessment and Land Use Planning

COM Chama cha Mapinduzi (Revolutionary Party)

EALB East African Literature Bureau

EAPH East African Publishing House

ERB Economic Research Bureau

FAO Food and Agriculture Organization

TANU Tanganyika African National Union

TPH Tanzania Publishing House

ISBN 91-7106-187-8

Printed in Sweden by

Ofisetcenter ab, Uppsala 1981 


\section{ACKNOWLE'DGEMENTS}

This bibliography would not have been initiated or completed without the assistance of Yvette Scheven, the Africana Librarian a the University of Illinois. Her repeated advice, counsel and editorial work were invaluable. The staffs of the libraries of the University of Illinois, Brown University, Northwestern University, Boston University, the Library of Congress and, in the past, the University of Dar es Salaam have provided considerable assistance. And, many Tanzanian and non-Tanzanian scholars who have studied ujamaa villages have directly and indirectly assisted in its compilation. The help of a 11 these colleagues has made this bibliography possible.

D. $\mathrm{MCH}$ 
TABLE OF CONTENTS

I. INTRODUCTION

A. Subject 1

1. Ujamaa villages 1

2. Their significance 2

3. Their literature 2

B. Bibliography 3

1. Character of existing bibliographies 4

2. Character of this bibliography 5

II, REFERENCES

A. Evolution of the Ujamaa Village Strategy for Rural Development

1. Experiences and conditions in rural Tanzania 6

2. Ideas defining the ujamaa village undertaking 8

B. Formation of Ujamaa Villages 10

1. Establishment of villages 10

2. Initiation of communal activities 13

C. Character of Ujamaa Villages $\quad 16$

I. Case studies 16

2. Role of the government/party 22

3. Agricultural activities 26

4. Non-agricultural activities 30

5. Villagers and village leaders 34

D. Evaluation of the Ujamaa Village Approach to
Rural Development

1. Review of the effort 35

2. Assessment of success 42

$\begin{array}{lll}\text { E. General Sources: Journals, Newspapers \& } & 46 \\ \text { Bibliographies }\end{array}$

1. Journals 46

2. Newspapers 47

3. Bibliographies 47

III. INDEXES

A. Subject Index

B. Author Index 


\section{INTRODUCTION}

\section{A. The Subject}

Tanzania's effort to build ujamaa villages has attracted the attention of leaders and scholars from throughout the world. It has been the keystone of the country's struggle for both rural development and socialist transformation. As a result, it has been the focus of many empirical studies and much theoretical debate. Nevertheless, the contribution of these works to the building of both specific and general knowledge often has been limited by a lack of awareness of the research of others. This bibliography seeks to provide a relatively comprehensive guide to the literature on ujamaa villages.

\section{Ujamaa villages}

The expression "ujamaa village" has assumed a wide variety of meanings since it was first used by President Julius Nyerere in 1967 to refer to settlements where people would "live and work together for the good of all." Initially, it was applied to virtually every newlyformed village, regardless of its characteristics. In some areas officials categorized these ujamaa villages according to the degree of progress they saw toward what they conceived to be the ideal form. Because perceptions varied among officials, a "stage one" village in one part of the country differed from a "stage one" village in another part of the country. Nevertheless, almost a 11 the new villages were considered ujamaa villages. By the early 1970s, though, officials began to abandon this practice. Some villages were so different from the original idea that they were called "development villages" or "permanent villages" instead of ujamaa villages. The practice was not universal, for many officials argued that it discouraged evolution into the vaguely defined ideal form. Finally, in 1975, the central government acted to end the confusion by obtaining passage of the Villages and Ujamaa Villages Act. It established formal procedures for the classification of settlements as either villages or ujamaa villages. All settlements had first to be registered as the former before they could be considered for the latter status. The immediate effect was the dejure abolition of ujamaa villages, for it was several years before any obtained registration. Yet, despite the fact that settlements were no longer designated ujamaa villages in law, in common practice the expression continued to be used widely.

In order to avoid problems caused by changes in conceptualization and to make this bibliography as inclusiveas possible, a broad definition 
of "ujamaa village" has been employed. It is used to refer to all those settlements in Tanzania whose formation or reorganization is a consequence of either the ideas outlined in President Nyerere's policy paper Ujamaa Vijijini or the subsequent modifications of those ideas in the process of their realization. Most of the new rural settlements in Tanzania at least until the late $1970 \mathrm{~s}$ fall within such a conceptualization.

\section{Their significance}

In february 1967 the Arusha Declaration was adopted by the National Executive Committee of the sole political party in mainland Tanzania, the Tanganyika African National Union (TANU). It called for a society based on principles President Nyerere labeled "ujamaa," usually translated "socialist" but more meaningfully translated "family." In September Nyerere published a subsidiary document titled Ujamaa Vijijini, meaning "Ujamaa in the Villages." He argued that to make the country socialist, the rural areas where $95 \%$ of the population lived had to become socialist. That meant that peasants ought to live and work together for the good of all in settlements he called ujamaa villages. It was estimated at the time that $85 \%$ of the rural population of about 11 million people lived in scattered homesteads, so the task of creating villages that would develop along socialist lines was an immense one. At first peasants were merely encouraged to live in villages, but compulsion soon began to be applied. Following the President's declaration late in 1973 that everyone would have to live in villages by December 1976, massive operations were organized throughout the country. By 1977 about 90 \% of the rural population was living in villages. These were to be the foundation for all future rural development in Tanzania. No rural development undertaking whether directed toward socialist or non-socialist goals has directly affectzd the lives of as many Africans as the ujamaa village undertaking in Tanzania. And, no development effort has attracted as many leaders and delegations from all parts of the world seeking to examine what might be a model applicable to their own countries which would facilitate rapid rural development and/or socialist transformation.

\section{Their literature}

There is an extensive literature, both descriptive and theoretical, on the formation and nature of ujamaa villages. It has been written by people of a variety of nationalities with a variety of ideological viewpoints employing a variety of analytical skills. Tanzanians 
have produced or helped produce a substantial proportion of the studies. One reason is the decision of the party in 1967 to involve students more directly in socialist development. As a result, many university students have conducted field research as part of their course work or have assisted faculty members in on-going research. Most of the primary research by non-Tanzanians has been undertaken by those employed at the University of Dar es Salaam or in government ministries.

Many of the studies of ujamaa villages contain "ideological" or "theoretical" components. That is, they seek to suggest how what they see fits-within the general process of socialist transformation. Several of them make suggestions of what should be done to overcome particular problems.

The quality of the studies varies considerably. Whether or not a particular work has been published is much less correlated with its substantive contribution in the case of this body of literature than in the case of that on many other subjects. For example, important works prepared by students such as Henry Mapolu's M.A. thesis, remain unpublished. Significant Ph.D. dissertations, such as those by Justin Maeda and Frances Hill, have not been published yet. And, only recently did any of Michaela von Freyhold's works appear in print, though insightful studies of hers have existed in mimeographed form for many years.

Most of the literature on ujamaa villages is in English. A high proportion of relevant government publications, though, are in Swahili. There are some secondary studies in French, a few in German and still fewer in other languages. The spectrum of interpretations of the ujamaa village effort does not appear to be very closely correlated with the language used in the study. One can find in English, for example, virtually the entire range of perspectives.

\section{B. The Bibliography}

Partly because much of the literature on ujamaa villages is in mimeographed form, standard bibliographies fail to include a substantial proportion of the studies which have been written. A lack of information about what research already has been done adversely affects the quest to build knowledge. For example, there are several case studies of ujamaa villages which make no reference to previous work which has been done in the village under consideration. The findings 
of a study in one village have seldom been used as hypotheses in studies of other villages, probably because of a lack of awareness of them. As a consequence, the contribution that research might make to understanding the specific case of ujamaa villages and the general case of the transition to socialism is limited. There is, then, a clear need for a bibliography on the subject.

\section{Character of existing bibliographies}

There are several bibliographies that appeared during the 1970s which contain references to works on ujamaa villages. Citations can be found scattered through the standard Africana bibliographies. And, others can be found in bibliographies dealing specifically with Tanzania (see items nos. 478 to 486). Tanzania Notes and Records has a section each year titled "Tanzania Bibliography" which lists under subject headings materials on Tanzania. Although there is no subject heading "ujamaa villages," some relevant items appear under such topics as "Agriculture," "Sociology" and "Political Science." M. Sumar and E. McGee's bibliography, National Policies of Tanzania, contains a section headed "Ujamaa Villages" (pp. 19-24) which consists of citations of a few journal articles and several newspaper reports and news releases on ujamaa villages. The Deutsches Institut fir Afrika-Forschung bibliographies compiled by Ties Moller in 1972 and by Ties Moller and Anne Jansen in 1974 do not have an index heading for ujamaa villages, but do have one for "ujamaa" with 30-40 items listed under each, several of which are relevant to ujamaa villages. Volkhard Hundsdorfer and Wolfgang Küper's bibliography published in 1974 contains a subsection on ujamaa villages containing 44 items (pp. 141-144 and 146). A bibliography of studies that are not widely available is that compiled by Ibrahim Kai-Samba, et al., Development for Self-Reliance, published by the Faculty of Agriculture Library. It contains a subject index which lists many items on ujamaa villages. Some of these items are duplicated by James De Vries' Selected Bibliography on Agricultural Extension in Tanzania published in 1978 by the Department of Rural Economy at the Faculty of Agriculture. It is simply a listing of materials without a subject index to ujamaa villages. Finally, James Kocher and Beverly Fleisher compiled A Bibliography on Rural Development in Tanzania and published it in 1979. Although it contains no subject index, it lists about 75 relevant items under the subject heading "Ujamaa, Villagization and Planned Settlement." None of these bibliographies contains more than a small proportion of the works dealing with ujamaa villages. 


\section{Character of this bibliography}

This bibliography contains most of the works relevant to ujamaa villages produced'up to 1980. It is based on materials collected in Tanzania by the compiler during several years of research on the subject, studies identified by colleagues, works cited in bibliographies and collections held by major libraries in the United States and Tanzania. Most of the materials have been examined by the compiler, though a few have been included if they were cited repeatedly in other sources. Some of the works may be obtained only in Tanzania, though most of them are available in at least some major libraries abroad. It is likely that more and more of the items contained in this bibliography will become available outside Tanzania as library collections grow.

The dominant theme of each work has been used to classify it into one of four major and then one of several minor categories, as shown in the table of contents. The four major subdivisions group materials that deal with the evolution of the strategy, the formation of villages, the character of the villages and evaluations of the undertaking. Some of the more comprehensive works contain information about all the major and the minor categories. Nevertheless, they have been classified into only one on the basis of the compiler's subjective assessment of the major theme. In order to help the user find materials that are relevant to, yet excluded from, these categories, a subject index is included. The subject index does not include topics only briefly mentioned in a given work. For example, village organization may be dealt with briefly in a case study but not included in the subject index. The subject index does contain a listing of most villages studied and, wherever possible, the districts in which they are found. Because some district names and boundaries have changed over the years, the district at the time of the most recent study is given. District and regional subject headings are also used to direct the user to materials on villages within those areas. The combination of categorization by dominant theme and a subject index should facilitate the user's identification of relevant materials. Finally, an author index is included to aid in the location of works known to the user only by the author's name. 


\section{I. REFERENCES}

There are a few variations from normal forms of citation in the following list of references. Mimeographed material is not distinguished explicitly from printed material, because the distinction is of limited significance to the user. The country of publication is not identified for those cities whose locations are widely known or are found in Tanzania for the sake of simplicity. The cities in which the main campuses of the University of Dar es Salaam and the University of Nairobi are located are not given to avoid redundancy. The Faculty of Agriculture of the University of Dar es Salaam, though, is located at Morogoro.

Following main citations, other sources of the items are listed. In the case of the frequently republished writings of President Nyerere, only the volume of his collected works in which the article appears is given following the main citation. For the few items which have not been examined by the compiler/author, the source of the citation is listed in a comment following the reference. Other relevant information about citations is included where appropriate in similar comments .

\section{A. Evolution of the Ujamaa Village Strategy for Rural Development}

Works whose major theme concerns the evolution of the ujamaa village strategy are divided into two parts: the first includes those related to the experiences of, or conditions in, rural Tanzania that shaped the ujamaa village approach; the second includes those related to the philosophy behind, or program of, that approach. The list of references pertaining to the former is relatively selective; that pertaining to the latter is relatively exhaustive.

\section{Experiences and conditions in rural Tanzania}

1. BRAIN, JAMES. "Is transformation possible? Styles of settlement in post-independence Tanzania." African effairs 76, no. 330 (1977) : 231-245.

2. CHIMото, N. N. O. "Ruvuma Development Association (R.D.A.)." Student paper, Department of Sociology, University of Dar es Salaam, 1974. 81 p. In Field Research in Tanga ujamaa villages, Department of Sociology, University of Dar es Salaam, 1975 .

3. CLIFFE, LIONEL. "Traditional ujanaa and modern producer cooperatives in Tanzania." In cooperatives and rural development in East Africa, edited by Carl Gösta Widstrand, pp. 38-60. New York: Africana, 1970. 
CLIFFE, LIONEL and GRIFFITHS CUNNINGHAM. "Ideology, organization and settlement experience in Tanzania." In Socialism in Tanzania, Vol. 2, edited by Lionel Cliffe and John Saul, pp. 131-140. Dar es Salaam: EAPH, 1973.

CUNNINGHAM, GRIFFITHS. "The Ruvuma Development Association, an independent critique." Mbioni 3, no. 2 (1966) : 44-55.

DUMONT, RENE. Tanzanian agriculture after the Arusha Declaration: a report. Dar es Salaam: Government Printer for Ministry of Economic Affairs and Development Planning, 1969. 62 p. Prepared in 1967.

ELIMAN, ANTONY. "Kitete: a land settlement scheme in northern Tanzania." Land reform, no. 1 (1967): 12-21.

GEORGULAS, NIKOS. "Settlement patterns and rural development in Tanganitika." (Occasional paper no. 29). Program of Eastern African Studies, Syracuse University, New York, May 1967. 40 p. Abstracted in Ekistics 24, no. 41 (1967): 180-192.

GUNZA, J. K. F. "Rwamkoma pilot village settlement scheme: a case study." Student dissertation, Department of Political Science, University of Dar es Salaam, 1971. 24 p.

10. IBBOTT, RALPH. "The Ruvuma Development Association." Mbioni 3, no. 2 (1966): 3-43.

11. KATES, R. W., J. MCKAY and L. BERRY. "Twelve new settlements in Tanzania: a comparative study of success." Paper presented a the University of East Africa social sciences council conference, Kampala, 30 December 1968 - 5 January 1969. In University of East Africa social sciences councii conference 1968/69, Geography papers published by Makerere Institute of Social Research, pp. 63-100.

12. KAWAWA, R. M. "New approaches to rural development," Mbioni 2, no. 11, (1966): 4-15.

13 KONTER, J. H. "Economic imperatives for a socialist develoument in'the rural economy of Nyakyusa (Tanzania)." cultures et développement 10, no. 3 (1978): 409-427.

LANDBERG, LEIF C. W. "Ujamaa vs. Udugu and Umoja, institutional opposition and ideological congruence within a Tanzanian fishing cooperative." Paper presented at the annual meeting of the African Studies Association, Syracuse, New York, November 1973, 19 p.

15. MCKAY, JOHN. "A review of rural settlement studies for Tanzania." East African geographical review, no. 6 (1968): 37-49.

16. MWANSASU, BISMARK U. "TYL settlement schemes, the whys and wherefores of success." Kivukoni College, 1966.

17. NELlis, J. R. "Prelude to Arusha: a study of productivity problems on a rural development scheme in Tanzania." Journal of administration overseas 11, no. 3 (1972): 169-181.

NEWIGER, NIKOLAUS. "Cooperative village settlements in Tanzania." Paper presented at the regional seminar on cooperative farming, FAO, New Delhi, India, May 1966. 13 p. 
19. NEWIGER, NIKOLAUS. "Village settlement schemes: the problems of cooperative farming." In Smallholder farming and smallholder development in Tanzania, edited by Hans Ruthenberg, pp. 251-273. Munich: Info-Institut fur Wirtschaftsforschung, 1968.

20. NG'ASI, A. P. "Kijiji cha ujamaa cha Litowa." [The ujamaa village of Litowa]. Ujamaa, no. 4 (1968): 19-28.

21. PITBLADO, J. ROGER. "A review of agricultural land use and land tenure in Tanzania." (BRALUP research notes no. 7). University of Dar es Salaam, June 1970. 41 p.

22. SAUL, JOHN S. "Marketing cooperatives in Tanzania: a case study i n resource allocation and inequality." Paper presented at the East African universities social science conference, Nairobi, December 1969. 16 p. Revised and published as "Marketing cooperatives in a developing country: the Tanzanian case" in Taamuli I, no. 2 (1971): 30-50; i n Peter Worsley, ed., Two blades of qrass: rural cooperation in developing societies (Manchester: Manchester University Press, 1971), pp. $347-370$.

23. TANZANIA, RURAL SETTLEMENT COMMISSION, A report on the village settlement programme from the inception of the rural settlement commission to 31 December, 1965. Dar es Salaam: Government Printer, 1966. 49 p.

24. TEMU, PETER E. "Tanzanian experience with rural settlement schemes over the past two decades. "South African journal of African affairs 3, no. 2 (1973): $33-36$.

2. Ideas defining the ujamaa village undertaking

25. BULEGI, S. A. "Sheria ya vijiji ya 1975 na sheria ya madaraka mijini ya 1976." [The villages law of 1975 and the urban development law of 1976]. Ujamaa, no. 52 (1977): 28-40.

26. KIMITI, P. K. Siasa ya Tanu katika kilimo: twendeni vijinjimi. [policies of Tanu in agriculture: let's go to the villages]. Dar es Salaam: Wizara ya Kilimo, Chakula na Ushirika, n.d. $41 \mathrm{p}$.

27. MAPUNDA, G. "Ujamaa ni silaha kubwa ya kupigana na umaskini, ujinga na magonjwa." [socialism is an important weapon in the battle with poverty, ignorance and disease]. Ujamaa, no. 4 (1968): $14-18$.

28. MSAMBICHAKA, L. A. "A theoretical analysis of the fundamentals of agricultural development in a non-capitalist developing Tanzania in the state sector and agricultural producer cooperatives." Paper presented at the annual East African universities social science conference, Dar es Salaam, December 1973. $41 \mathrm{p}$.

29. MSEKWA, PIUS. "Towards party supremacy: the changing pattern of relationships between the National Assembly and the National Executive Committee of TANU before and after 1965." Master's thesis, Department of Political Science, University of Dar es Salaam, 1974. 
30. MUSHI, SAMUEL S. "Modernization by traditionalization: ujamaa principles revisited." Taamuli 1, no. 2 (1971): 13-39.

31. NYERERE, JULIUS K. "The Arusha Declaration." In Ujamaa, essays on socialism by Julius Nyerere, pp. 13-37. Dar es Salaam: Oxford University Press. 1968. Reprinted in Julius Nverere, Freedom and socialism (Dar es Salaam: Oxford university Press, 1968), pp. 231-250.

32. NYERERE, JULIUS K. "Hotuba ya $\mathrm{r}$ a is wa chama kwenye mkutano mkuu wa TANU wa 16." [Speech of the president of the party a the $16 \mathrm{th}$ biennial conference of TANU]. In Maendeleo ni kazi. edited by Idara ya Habari, Makao Makuu ya TANU, pp. 1-27. Dar e s Salaam: TANU, 1973.

33. NYERERE, JULIUS K. "Presidential circular no. 1 of 1969." In Rural-cooperation in Tanzania, edited by Lionel Cliffe, et al., pp. 27-34. Dar es Salaam: TPH, 1975.

34. NYERERE, JULIUS K. President's report to the TANU conference, sept. 1973. Dar es Salaam: Government Printer, 1973. 22 p. Reprinted as "Progress comes with production", The African review 3, no. 4 (1973): 519-539.

5. NYERERE, JULIUS K. "Progress in rural areas." In Ujamaa, essays on socialism by Julius Nyerere, pp. 178-186. Dar es Salaam: Oxford University Press, 1968. Reprinted in almost identical form as "Implementing rural socialism" in Julius Nyerere, Freedom and development (Dar es Salaam: Oxford University Press, 1973), pp. 5-11.

36. NYERERE, JULIUS K. Socialism and rural development. Dar es Salaam: Government Printer, 1967. 31 p. Reprinted in Julius Nyerere, Ereedom and socialism (Dar es Salaam: Oxford University Press, 1968), pp. 337-366. Swahili version of this paper was published under the title Ujamaa vijijini. (See item no. 38 ).

37. NYERERE, JULIUS K. "Ujamaa: the basis of African Socialism." In Freedom and Unity by Julius Nyerere, pp. 162-171. London: Oxford University Press, 1967. Originally prepared in 1962.

38. NYERERE, JULIUS K. Ujamaa vijijini. [socialism in the villages]. Dar es Salaam: Government Printer, 1967. 33 p. Enclish version of this paper was published under the title Socialism and rural development. (See item no. 36)

39. "Saba Saba Day: Mwalimu speaks to African development." African development 8, no. 7 (1974): T7-T8.

40. TANZANIA. IDARA YA MAENDEIEO YA UJAMAA NA USHIRIKA. OFISI YA WAZIRI MKUU NA MAKAMU WA PILI WA RAIS. Sheria ya kuandikisha vijiji navijiji vya ujamaa. [The law for registering villaqes and ujamaa villages]. Dodoma: Ofisi ya Waziri Mkuu na Makamu wa Pili wa Rais, 1975. 52 p. Contains the law,

Kawawa's explanation of the law, forms and subsidiary legis lation.

41. TANZANIA. LAWS, STATUTES, ETC. "The Villages and Ujamaa Villages (Registration, Designation and Administration) Act (No. 21 of 1975)." In Acts of Tanzania, 1975, pp. 305-312. The Regulations, Order, Notice and Directions issued under this act appear in supplement No. 38 (Subsidiary Legislation to 
the Gazette of the United Republic of Tanzania, Vol. 56, No. 35, 22 August, 1975, pp. 183-206). Both the English and Swahili versions were re-published in Tanzania, Idara ya Maendeleo ya Ujamaa na Ushirika, Ofisi ya Waziri Mkuu na Makanu wa Pili wa Rais, Sheria ya kuandikisha vijiji na vijiji vya ujamaa, pp. $23-34$ and $34-48$, respectively. (See item no. 40.)

\section{B. Formation of Ujamaa Villages}

The original conception of an ujamaa village as a place where people lived and worked together for the good of all required two steps: the formation of a village and the initiation of communal activities. Fn ujamaa village required the conjunction of these two activities.

\section{Establishment of villages}

42. BAKULA, B. B. "The effect of traditionalism on rural development: the case of Omurunazi ujamaa village, Bukoba." Student dissertation, Department of Political Science, University of Dar es Salaam, 1969. 40 p. Revised and published in J. H. Procter, ed., Building ujamaa villages in Tanzania (Dar es Salaam: Department of Political Science, University of Dar es Salaam, 1971), pp. 15-32.

43. BANDUKA, N. M. "The aspects of establishing ujamaa villages in Pare district, Tanzania." Student dissertation, Department of Political Science, University of Dar es Salaam, 1971. $45 \mathrm{p}$.

44. BOESEN, JANNIK. "Development and class structure in a smallholder society and the potential for ujamaa." (Research paper A. 72.16). Copenhagen: Institute for Development Research, 1972. 100 p.

45. BOESEN, JANNIK. "Tanzania: from ujamaa to villagisation." (Research paper A. 76.7). Copenhagen: Institute for Development Research, 1976. 25 p. Reprinted in Bismarck Mwansasu and Cranford Pratt, eds., Towaras socialism in Tanzania (Toronto: University of Toronto Press, 1979), pp. 125-144.

46. BOESEN, JANNIK; BIRGIT STORGAKD MADSEN and TONY MOODY. U jamaa: socialism from above. Uppsala: Scandinavian Institute of African Studies, 1977. 186 p.

47. CUNNINGHAM, GRIFFITHS. "The ujamaa village movement in Tanzania." Rural Africana, no. 13 (1971): 28-35.

48. CUNNINGHAM, GRIFFITHS. "The ujamaa village plans of Tanzania." In Intermediate technology and integrated extension, conference report, Christian Rural Fellowship of East Africa, Moshi, September 1969, pp. 14-18.

49. DABANA, A. P. "Possibilities of socialism in a Geita trading settlement." Student dissertation, Department of Political Science, University of Dar es Salaam, 1970. 42 p. 
50. HAULLE, D. M. and WACHIYE-MUNYASIA. "Building socialis m in

Lushoto: the establishment of Malibwi ujamaa village." 25 p.

In Field research in Tanga ujamaa villages, Department of

Sociology, University of Dar es Salaam, 1975. Written in 1974.

51. HIRST, M. "Recent villagization in Tanzania." Geography 63, part 2, no. 279 (1978): $122-125$.

52. IBBOTT, RALPH. "The disbanding of the Ruvuma Development Association in Tanzania." A mimeographed letter, War on Want, London, November 1969. 5 p.

53. JAMES, R. W. "Implementing the Arusha Declaration: the role of the legal system." The African review 3, no. 2 (1973): 178-208. Reprinted in the Dar es Salaam University law journal 5 (1973): 1-37.

54. KAVURA, DICKY. "Problems ana prospects of establishing ujamaa villages in Kibondo district." Student dissertation, Department of Political Science, University of Dar es Salaam, 1970. $9 \mathrm{p}$

55. KAZI, CONSTANTINE MASHENENHE. "Implementing ujamaa village policy in Morogoro district: a study of the problems of socialist construction a t Mkata ujamaa village." Master's thesis, Department of Political Science, University of Dar es Salaam, 1975. $116 \mathrm{p}$.

56. KAZIMOTO, A. A. "Prospects for building ujamaa villages." Mbioni 5, no. 3 (1968): 3-12. Reprinted in Lionel Cliffe and John Saul, eds., Socialism in Tanzania, Vol. 2 (Dar es Salaam: EAPH, 1973), pp. 186-188.

57. KISULA, P. A. "Prospects of building ujamaa villages in Mwanza district." Student dissertation, Department of Political Science, University of Dar es Salaam, 1973. $31 \mathrm{p}$.

58. LUTTERELL, WILIIAM L. "Villagisation, cooperative production and rural cadres: strategies and tactics in Tanzanian socialist rural development." (ERB paper 71.11.) University of Dar es Salaam, 1971. 81 p.

59. LYIMO, FRANCIS FANUEL. "Problems and prospects of ujamaa development in Moshi district." Master's thesis, Department of Sociology, University of Dar es Salaam, June, 1975.

60. MAGATTI, J. O. "Operation Vijiji: the effect of the delivery of social services: Tarime district." Student paper, Department of Rural Economy, Faculty of Agriculture, University of Dar es Salaam, 1976. 97 p.

61. MATANGO, R. R. "Formation of ujamaa villages amona the semipastoralists of North Mara." 18 p. In Field research in Tanga ujamaa villages, Department of Sociology, University of Dar es Salaam, 1975. Written in 1974.

62. MBOYA, G. R. "Feasibility of ujamaa villages in Kilimanjaro." Student dissertation, Department of Political Science, University of Dar es Salaam, 1970. 13 p. Slightly revised and published in J. H. Procter, ed., Building ujamaa villages in Tanzania (Dar es Salaam: TPH, 1971), pp. 64-69. 
63. MCHENRY, DEAN E., JR. "Policy implementation in rural Africa: the case of ujamaa villages in Tanzania." Paper presented at the annual meeting of the African Studies Association, Syracuse, November 1973. 22 p.

64. McHENRY, DEAN E., JR. Tanzania's ujamaa villages: the implementation of a rural development strategy. Berkeley: Institute of International Studies, University of California, 1979. $268 \mathrm{p}$.

65. MCHUMO, ALI S. "Sheria na mahakama kama mojawapo ya vyombo muhimu vya kutekeleza siasa ya ujamaa." [The law and the courts as one of the important tools in the implementation of the policy of ujamaa]. Ujamaa, no. 50 (1976): 1-32.

66. MESAKI, SIMEON. "Operation Pwani, Xisarawe district: implementation problems." Master's thesis, University of Dar es Salaam, June 1975.

67. MISSANA, S. M. "Problems of implementing ujamaa in Bunda area: a case study of Igundu ujamaa village." 15 p. In Field research in Tanga ujamaa villages, Department of Sociology, University of Dar es Salaam, June 1975.

68. MUSHI, S. A. SANGALE. "The problems of starting ujamaa villages in Kilimanjaro district." Student paper prepared for the Institute of Adult Education, University of Dar es Salam, 1972? 7 p.

69. MUSOKE, I. K. S. "The establishment of ujamaa villages in Bukoba: Rugazi (Nyerere) village, a case study." Student dissertation, Department of Political Science, University College, Dar es Salaam, 1970. 45 p. Revised and published as "Building socialism in Bukoba: the establishment of Rugazi (Nyerere) Ujamaa village" in J.H. Procter, ed., Building ujamaa villages in Tanzania, (Dar es Salaam: TPH, 1971), pp. 1-14; and in International journal of politics 4, no. 4 (Winter $1 9 7 4 / 7 5 \longdiv { : 1 0 2 - 1 1 8 . }$

70. MWAPACHU, JUMA VOLTER. "Opperation planned villages in rural Tanzania: a revolutionary strategy for development." Mbioni 7, no. 11 (1975): 5-39. Reprinted in The African review 6, no. 1 $(1976): 1-16$.

71. NDUNGURU, K. K. "Possibility for the growth of ujamaa villages along Lake Nyasa: a case study of Ngumbo subdivision, Mbinga district. "Student dissertation, Department of Political Science, University of Dar es Salaam, 1971. $47 \mathrm{p}$.

72. PIPPING, KNUT. "Cooperation." In Landholding in the Usangu Plain: A survey of two villages in the southern highlands of TanZania by Knut Pipping, pp. 72-90. (Research report no. 33). Uppsala: The Scandinavian Institute of African Studies, 1976.

73. POMJEE, C. K. J. "The social and economic factors affecting establishment and viability of an ujamaa village in Morogoro district." Student paper prepared for the Department of Rural Economy, University of Dar es Salaam. Morogoro, 1973. Typescript. 36 p. Cited in Ibrahim B. Kai-Samba, et al., Development for self-Reliance. (Item no. 480). 
74. "Problems of rural development: the case of Mbaga, Same-Mbaga division, Pare district." 32 p. In A collection of essays on ujamaa villages, by E.O. Kayombo, et al. Four student dissertations: Department of Political Science, University of Dar es Salaam, 1971.

75. PROCTOR, J. H., ed. Building ujamaa villages in Tanzania. Dar es Salaam: TPH, 1971.69 p. Pagination is slightly different on the 1974 reprinting, so that it consists of only 68 p.

76. RALD, JORGEN. "Ujamaa, problems of implementation (experiences from West Lake)." (BRALUP research report no. 10.). University of Dar es Salaam, May 1970. 37 p.

77. RUGEMARILA, R. H. "The economic impact of Operation Kigoma: Case study, Kibondo district, the Waha." Student paper, Department-of Rural Development, Institute of Development Management, Mzumbe, 1976. 96 p.

78. SAIBUL, S. A. OLE. "Social change among the pastoral Maasai in Tanzania in response to the ujamaa vijijini policy of TANU since the Arusha Declaration of 1967." Master's thesis, Department of Political Science, University of Dar es Salaam, 1974. 99 p.

79. SPECIAL CORRESPONDENT. "S ocialist land reform in Tanzania." The African communist, no. 45 (1971): 71-84.

80. "Tanzania: collectivising the villagers." Africa confidential 15, no. 1 (4 January 1974): 6-8.

81. WKOVIC, BRANISLAU. "Involvement of the nation in building ujamaa villages." Mbioni 5, no. 9 (1970): 5-11.

82. WAGAO, JUMANNE H. "Operation Kigoms: Kibondo district, phase two - progress." Student paper, Department of Economics, University of Dar es Salaam, December 1975. 19 p.

83. WILLIAMS, DAVID. "Law and socialist rural development." Eastern Africa law review 6, no. 3 (1973): 193-213. Presented a the East African universities social science conference, Dar es Salaam, December 1973. 34 p.

2. Initiation of communal activities

84. BUGENGO, JAMES and J. P. B. MUTANGIRA. "The Nyarubanja system and both developmental and ujamaa villages in West Lake region, Tanzania." Paper presented at an ERB seminar, University of Dar es Salaam, November 1975. 23 p.

85. BUGENGO, JAMES, J. P. B. MUTANGIRA and J. B. K. RWELENGERA. "The Nyarubanja system and ujamaa villages development in West Lake region." (ERB paper 76.1). University of Dar es Salaam, 1976. $72 \mathrm{p}$. An expansion and revision of James Bugengo and J.P.B. Mutangira, "The Nyarubanja system and both developmental and ujamaa villages in West Lake region, Tanzania" (Item no. 84 ).

86. BUNDAKILA, J. T. "The role of cooperatives in rural development: a comment." In Agricultural extension in ujamaa village development: papers and proceedings of a workshop, edited by Hermann Hansel, etal., pp. 70-75. Morogoro: University of Dar es Salaam, $19 \overline{975 .}$ 
CHALE, HARRY F. "Emergent large farmers and the problems of implementation of ujamaa vijijini policy in Usangu (Mbeya district)." Student dissertation, Department of Political Science, University of Dar es Salaam,, 1973. 45 p.

88. COOPERATIVE UNION OF TANGANYIKA. Shughuli za vyama vya ushirika katika vijiji vya ujamaa. The work of cooperative societies in ujamaa villages!, Dar es Salaam: Union of Tanganyika, n.d. 13 p.

89. MUUNGANO WA VYAMA VYA USHIRIKA TANGANYIKA. IDARA YA ELIMU NA UTANGAZAJI. Ushirika wetu. [Our cooperatives]. Dar es Salaam: Cooperative Union of Tanganyika Press, 1977. 92 p.

90. FELDMAN, DAVID. "Ismani and the rise of capitalism: Ideology and practice and Tanzanian rural development." Paper presented a the seminar on changes in Tanzanian rural society and their relevance for development planning, Afrika-Studiecentrum, Leiden, Netherlands, December 1970. 38 p.

FELDMAN, DAVID. "Problems in achieving rural socialism in Tanzania." (Mimeo-series 14 ). Institute of Development Studies, University of Sussex, Brighton, July 1968. 35 p. Republished as "Les problems de la realisation du socialisme rural en Tanzania", Etude Congolaises 11, no. 4 (1968): 105-135.

FELDMAN, DAVID and RAYAH, FELDMAN. "Cooperation and the production environment: some explorations among social and economic factors affecting agricultural cooperation." (ERA paper 69.12). University College, Dar es Salaam, 1969. 20 p. Published in Kwan S. Kim, Robert B. Mabele and Michael J. Schultheis, eds., Papers on the political economy of Tanzania (Nairobi: Meineman, 1979), pp. 14-23.

93. FELDMAN, RAYAH. "Custom and capitalism: changes in the basis of land tenure in Ismani, Tanzania." (ERB paper 7). University of Dar es Salaam, 1971. 45 p. Published in the Journal of development studies 10, no. 3 (1974): 305-320.

94. FELDMAN, RAYAH. "Rural social differentiation and politica] goals in Tanzania." In Beyond the sociology of development: economy and society in Latin America and Africa, edited by Ivar Oxaal; Tony Barnett and David Booth, pp. 154-182. London: Routledge and Kegan Paul, 1975.

95. FREYHOLD, MICHAELA VON. "Rural development through ujamaa vijijini (some considerations based on experiences in Tanga)." Department of Economics, University of Dar es Salaam. 1972. 36 p. Based on research conducted in the first half of 1971 in collaboration with K.R. Kiravu, G. Kreuter, E.N. Makere, and D.C. Mbezi.

96. FUMBUKA, S. and H. MAPOLU. "U jamaa villages and cooperatives." Student paper, Department of Sociology, University of Dar es Salaam, 1973.

97. HYDEN, GÖRAN, ed. Cooperatives in Tanzania: problems of organisation building. Dar es Salaam: TPH, 1976. 93 p. The Library of Congress entry for this volume is Cooperatives in Tanzania: problems of organisation building/A.Z. Mutaha, et al. Dar es Salaam: TPH, 1976. It neglects to identify Göran Hydén as the editor. 
98. KIKWETE, JAKAYA M. "Bululu-vis-a-vis ujamaa village: a comparative studv of the traditional village system of the Wakwere with the ujamaa village." In Field research in Tanqa ujamaa villages, Department of Sociology, University of Dar es Salaam, 1975. 22 p. Prepared in 1974.

99. KINYONDO, S. R. "The building of socialism in Tanzania: Katoma traditional village, a case study of problems and possibilities of transforming a traditional village into an ujamaa village." Student dissertation, Department of Political Science, University of Dar es Salaam, 1971. 140 p.

100. MAHECHA, M. A. C. "Forms of cooperation as a potential base for the establishment of ujamaa living: Hongi village experience." 17 p. In Field research in Tanga ujamaa villages, Department of Sociology, University of Dar es Salaam, 1975.

101. MMUYA, MAX "'Bega kwa bega', nafasi yake katika wa ujamaa." ['Block farms', its potential in the buildnig of ujamaa]. Ujamaa, no. $51(1977): 23-43$.

102. MODERNE', FRANK. "Evolution e t perspectives de Ia cooperation agricole en Tanzanie." LEvolution and perspectives of agricultural cooperation in Tanzania]. Revue Francaise d'etudes politiques Africaines, no. 59 (1970): 65-90.

113. MOHAN, RAKESH. "On the conditions for successful cooperation in ujamaa villages in. Tanzania." Development Studies, University of Dar es Salaam, 1970? 26 p.

104. MWAKISYOABE, J. S. E. "Utekelezaji Wá Operesheni Maduka." [The implementation of Operation Maduka]. Ujamaa, no. 49 (1976): $1-24$.

105. NINDI, B. C. "The articulation of Ismani social economic structure and its implication for ujamaa vijijini policy."

Master's thesis, Department of Sociology, University of Dar es Salaam, June 1975.

106. NTIRUKIGWA, ESPERIUS $\mathrm{N}$. "The impact of traditional land tenure system on ujamaa villages: a case study of Kalebezo Buchosa in Geita." Student dissertation, Department of Political Science, University of Dar es Salaam, March, 1970. 34 p. Published in a slightly revised form as "The land tenure system and the building of ujamaa villages in Geita: a case study of Ralebezo" in J.H. Procter, ed., Building ujamaa villages in Tanzania. (Dar es Salaam: TPH, 1971), pp. 33-47

107. PLESKAC, JIRI. "Division of labour and distribution of output." Mbioni 6, no. 1 (1970): 12-24.

108. RUGUMISA, S. M. Mutual aid groups and their potential for agricultural development in Bukoba district with special reference to Bukabuye village." Paper presented at the East African universities social science conference, Dar es Salaam, December 1973. 20 p.

109. SAUI, JOHN S. "From marketing cooperative to producer cooperative." In Rural cooperation in Tanzania, edited by Lionel Cliffe, etal., pp. 287-307. Dar es Salaam: TPH, 1975. 
110. SAWE, L. M. M. "Linkage of government and local people in postering collective production in central Hai." Master's thesis, Department of Political Science, University of Dar es Salaam, 1975. $93 \mathrm{p}$.

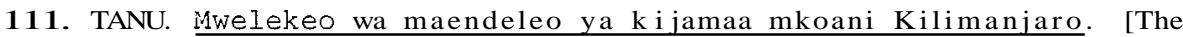
effort to develop socialism in Kilimanjaro region]. Dar es Salaam: Makao Makuu ya Chama ya Mkoa wa Kilimanjaro, March 1974. 69 p.

112. TANU. "Ujamaa in Sukumaland - an essay in cooperative development." In Rural cooperation in Tanzania, edited by Lionel Cliffe, etal., pp. 428-454. Dar es Salaam: TPH, 1975.

113. THODEN VAN VELZEN, H. U. E. "Some social obstacles to ujamaa: a case study from Rungwe." In Rural cooperation in Tanzania, edited by Lionel Cliffe, et al., pp. 346-359. Dar es Salaam: TPH, 1975. Written in 1970 .

114. THODEN VAN VELZEN, H. U. E. "Staff, kulaks and peasants." In Socialism in Tanzania, Vol. 2, edited by Lionel Cliffe and John Saul, pp. 153-179. Dar es Salaam: EAPH, 1973.

115. "Tobacco production in Tabora district: case study of Tutuo scheme." 21 p. In A collection of essays on ujamaa villages, by E.O. Kayombo, etal., Four student dissertations, Department of Political Science, University of Dar es Salaam, 1971.

\section{Character of Ujamaa.Villages}

The literature describing what ujamaa villages are and how they work is extensive. Although not easily categorized, it can be grouped under five headings: case studies, the role of the government/party in the villages, agriculture in the villages, non-agricultural activities in the villages and villagers and their leaders. Included in this listing are government publications meant for use in, as well as general studies of, ujamaa villages.

1. Case studies

116. BAMUGAYA, P. A. and G. KINDAMBA. "A study tour report on Tumbakose ujamaa village." Student paper, Institute of Adult Education, University of Dar es Salaain, 1972? 4 p.

117. "A brief summary about the study of Mseta ujamaa village," Student paper, Institute of Adult Education, University of Dar es Salaam, 1972. 3 p.

118. BUGENGO, JAMES. "Ujamaa in Mara Region." A paper presented at the East African universities social science conference, December 1973, Dar es Salaam. 18 p.

119. BULIGA and A. J. KIMOLA. "Ujamaa transformation in rural Tanzania: a case study of Kabuku Ndani ujamaa village, Tanga." Student paper, Department of Sociology, University of Dar es Salaam, 1974. 20 p. In Field research in Tanga ujamaa villages, Departmen $\_$of Sociology, University of Dar es Salaam, 1975 . 
120. DE VRIES, JAMES and LOUISE PORTMANN. "A study of ujamaa villages in Iringa region." Paper prepared for the UNDP/FAO Planning Team for the Iringa Third Five Year Plan, 1974. 103 p.

121. FREYHOLD, MICHAELA VON. "The potential for ujamaa in Handeni." University of Dar es Salaam. 1972. Based on research conducted in the first half of 1971 in collaboration with R.R. Kiravu, G. Kreuter, E.N. Makere and D.C. Mbezi.

122. FREYHOLD, MICHAELA VON. "The problem of $\mathrm{rural}$ development and the politics of ujamaa vijijini in Handeni." The African review 6 , no. 2 (1976): 129-142.

123. FREYHOLD, MICHAELA VON. Ujamaa villages in Tanzania: analysis of a social experiment. New York: Monthly Review Press, 1979. $201 \mathrm{p}$.

124. GAMA, M. O. "Sesenga ujamaa village (Morogoro region): the harvest situation in the year 1970." 10 p. In Ujamaa villages: a collection of original manuscripts, 1969-70, Tanzania, Ministry of Community Development. A typewritten manuscript collected by Eugene de Benko, Michigan State University, March 1971, in Dar es Salaam.

125. GITHINJI and MHINDi. "Kwamsisi ujamaa village." Student paper, Department of Sociology, University of Dar es Salaam, 1974. 38 p. In Field research in Tanga ujamaa villages, Department of Sociology, University of Dar es Salaam, 1975.

126. GOLLETH, M. J . and A. J . LYATUU. "A study of Mareu ujamaa village." Student paper, Institute of Adult Education, University of Dar es Salaam, January 1973. 7 p.

127. HANSEL, H. and S. A. SHAYO. "Report on a study tour to ulanga and Kilosa districts with emphasis on Ujamaa." Morogoro, 1972. Cited in James De Vries and H. Hansel, "Ujamaa villages as a strategy for rural development in Tanzania." (Item no. 349).

128. HILL, FRANCES REISENAUER. "Mobilization and participation in Tanzania." Ph.D. dissertation, Department of Political Science, Harvard University, August 1973. 503 p.

129. HYDEN, GÖRAN. "The struggle for success in rural cooperation: the case of Kabuku Ndani ujamaa cooperative society." University of Dar es Salaam, 1975. 33 p.

130. INDERBITZIN, IRIS and ANDRE JAQUEMENT. "Ngamu ujamaa village revisted." Mbioni 8, no. 2 (1973): 27-34.

131. KABIGI, K.; I. BINAMU; N. F. CHENGULA; N. M. URIO; J. J . SHENGENA and A. ALI. "Report on Mbambara ujamaa village." Mbioni 5, no. 7 (1969): $10-26$.

132. KAHAMA, KABARAMA. "Rural development strategy of modernization: a case study of ujamaa villages in Tanzania." Ph.D. dissertation, Claremont Graduate School, 1973. 149 p.

133. KAJULA, W. and M. KIKUDO. "Report on Ndoroboni ujamaa village." Student paper, Institute of Adult Education, University of Dar es Salaam. 1971? 2 p. 
134. KANDEGE and L. J. M. HUSSEIN. "Igongola ujamaa village, Njombe district, Iringa region." Student paper, University of Dar e s Salaam, 1972? Cited in R. D. Baldus, Zur Operationalen Effizienz der Ujamaa Kooperative Tansanias (Item no. 333).

135. KAUNDE, B. A. "Kitama village, Mtwara." 21 p. In Ujamaa villages: a collection of original manuscripts, 1969-70, Tanzania, Ministry of Community Development. A typewritten manuscript collected by Eugene de Benko, Michigan State University, March 1971, in Dar es Salaam.

136. KEHENGU, ELIAH M. and ISSAH B. L. LWESYA. "A study of IsansaItumpi ujamaa village." Student paper, Institute of Adult Education, University of Dar es Salaam, January 1973. 9 p.

137. KIBONA, H. A. and A. KANIKI. "Kicheba ujamaa village. "Student paper; Department of Sociology, University of Dar es Salaam, 1974. In Field research in Tanga ujamaa villages, Department of Sociology, University of Dar es Salaam, 1975.

138. KIMANI and MSIGWA. "Nkama ujamaa village." Student paper, Department of Sociology, University of Dar es Salaam, 1974. 15 p. In Field research in Tanga ujamaa villages, Department of Sociology, University of Dar es Salaam, 1975.

139. KURSCHNER, F. "Ujamaa-Dorfer in Tanzania: das Beispie1 Malili." Afrika Spectrum 8, no. 1 (1973): 88-96. Published as "Ujamaa villages in Tanzania: the example of Malili, "International Journal of politics 4, no.4 (Winter 1974-75): 88-101.

140. KUSILAWE, S. S. "A Survey of some ujamaa villages in Songea dis trict." (Field report no. 4). Rural Development Research Committee, University College, Dar es Salaam, 1968. Cited in R.D. Baldus, Zur Operationalen Effizienz der Ujamaa Kooperative Tansanias (Item no. 333).

141. LATIGO, S. "Goals and goal achievement in an organization: a case, Wangama ujamaa village, and related problems." Student paper, Department of Sociology, University of Dar es Salaam, 1973.

142. LEWIN, ROGER. "Matetereka." Mbioni 5, no. 3 (1969): 13-34. Reprinted Lionel Cliffe and John Saul, eds., in Socialism in Tanzania, Vol. 2, (Dar es Salaam: EAPH, 1973), pp. 189-194.

143. LEWIN, ROGER. "Ujamaa development in Sukumuland: a cattle-cotton ujamaa village." Kivukoni College, Dar es Salaam, 1968.

144. IJEWIN, ROGER. "Ujamaa village living a t Mbambara." Mbioni 4, no. 8. (1968): 2-7.

145. "Litowa village of ujamaa." African development, January 1969, pp. $8-10$.

146. LUGANGA, J and E. RASHIDI. "A Study of Namikunda ujamaa village." Student paper, Institute of Adult Education, University of Dar es Salaam, January 1973. 5 p.

147. MXMIMBO, W. S.; B. KIPANGA and N. MNONDWA. "A Study of Mtuunani ujamaa village." Student paper, Institute of Adult Education, University of Dar es Salaam, 1973? 9 p.

148. MAHINYA, T. "The case study of cooperation: Mtanana ujamaa village." Student paper, Institute of Adult Education, University of Dar es Salaam, 1972? 3 p. 
149. MAINA, B. W. and A. S. BANGO. "Basis of Tanzania's rural transformation: some organizational problems, a case study of Msaje ujamaa village." Student paper, Department of Sociology, University of Dar es Salaam, 1974. 19 p. In Field research in Tanga ujamaa villages. Department of Sociology, University of Dar es Salaam, 1975.

150. MAKERE, E. N. "Ujamaa villages in practice." Taamu?i 2, no. 2 $(1972)=17-26$.

151. MAPOLU, HENRY. "The social and economic organisation of ujamaa villages." Master's thesis, Department of Sociology, University of Dar es Salaam, September 1973. 113 p.

152. MASHEULA, AVIA. "Mkongo ujamaa village." 21 p. In U jamaa villages: a collection of original manuscripts, 1969-70, Tanzania, Ministry of Community Development. A mimeographed manuscript collected by Eugene de Benko, Michigan State University, March, 1971, in Dar es Salaam.

153. MATALISI, F. I. and A. CHIPATA. "Sociology of organization: research project in Tanga region." Student paper, Department of Sociology, University of Dar es Salaam, 1973? 12 p. In Field research in Tanga ujamaa villages, Department of Sociology, University of Dar es Salaam, 1975.

154. MAUMA, ROMMEL Z. "Uiamaa villaaes research report: Tabora district." 16 p. In Ujamaa villages: a collection of original manuscripts, 1969-70, Tanzania, Ministry of Community Development. A typewritten manuscript collected by Eugene de Benko, Michigan State University, March, 1971, in Dar es Salaam.

155. MBOYA, B. J. and A. MIHAYO. "Report from a two and half week participation observation of Mng'aro ujamaa village in Iushoto district - Tanga Region." Student paper, Department of Sociology, University of Dar es Salaam, 1974. 22 p. In Field research in Tanga ujamaa villages, Department of Sociology, University of Dar es Salaam, 1975.

156. MEENA, V. R.; W. K. MOSHI; MAHOMW; and J. S. M. KATHAMBI. "A study of Mtakuja ujamaa village. "Student paper, Institute of Adult Education, University of Dar es Salaam, January 1973. 7 p.

157. MHILU, S.G.; B. MAJILI and LUCAS. "A study of Chamwino ujamaa village." Student paper, Institute of Adult Education, University of Dar es Salaam, 1973? 8 p.

158. MLAWA, $\mathrm{H}$. and M. MSHANA "Kwemwewe ujamaa village in Tanga district, Tanga region." Student paper, Department of Socioloqy, University of Dar es Salaam, 1974. 29 p. In Field researchin Tanga ujamaa villages, Department of Sociology, University of Dar es Salaam, 1975.

159. MMBAGA, FRANR ELIEZER. "Villagization and decentralisation: Itobo ward, Nzega district." Student dissertation, Department of Political Science, University of Dar es Salaam, 1977. 68 p.

160. MOODY, TONY. "A comparative study of six ujamaa villages in Karagwe district, West Lake region." (Paper A.72.13). Copenhagen: Institute for Development Research, 1972. 18 p. 
161. MPUNGWE, A. R. A. "Ujamaa producer cooperative villages and socialist development: the experience of Morogoro region." Master's thesis, Department of Political Science, University of Dar es Salaam, 1975. 71 p.

162. MSUYA, E. A. and J. P. MOBERG. "Report on land use problems related to the development of Butiama ujamaa village." Department of Rural Economy, University of Dar es Salaam, Morogoro, 1975. 40 p. Cited i n Ibrahim B. Kai-Samba, e t al., Development for self-reliance (Item no. 480)

163. MTAKI, S.; D. MACHEMBA and S. KASORI. "A Study of Malili Ujamaa Village." Student paper, Institute of Adult Education, University of Dar es Salaam, January 1973, 10 p.

164. MTEI, S. and B. C. NINDI. "Ujamaa, Tanzania's crucial experiment: Changalikwa ujamaa village, a case study." Student paper, Department of Sociology, University of Dar es Salaam, 1974. 39 p. In Field research in Tanga ujamaa villages, Department of Sociology, University of Dar es Salaam, 1975.

165. MIEMBA, CLAUDIA. "Ujamaa villages i n Pare." 33 p. In U jamaa villages: a collection of original manuscripts, $1 \overline{969-70}$, Tanzania, Ministry of Community Development. A mimeographed manuscript collected by Eugene de Benko, Michigan State University, March 1971, in Dar es Salaam. Five manuscripts listed in the table of contents are really parts of the above work, i.e., "Gavao-Saweni," "Kigonigoni socialist village," "Kileo socialist village," "Kimungu-Makanga proposed socialist village," and "Manka-Mbaga ordinary village (and) overa 11 ujamaa problems in Pare district."

166. MUGOYA, MUNASSA. "U jamaa in practice: Mwalimu visits Makundusi." African development 6, no. 12 (1972): T.21.

167. MUSTAFA, KEMAL "The development of ujamaa in Musoma: a case study of Butiama ujamaa village." Master's thesis, Department of Sociology, University of Dar es Salaam, 1975.

168. MWAMBI, JAKA M. "Problems of creating uiamaa villaqes in Mqata." Student paper, Department of Sociology, University of Dar es Salaam, 1974. 11 p. In Field research in Tanga ujamaa villages, Department of Sociology, University of Dar es Salaam, 1975.

169. NDOMBA, C. J. "Development through ujamaa: Kihanga village experience." Student paper, Deoartment of Socioloay. University of Dar es Salaam, 1974. 17 p. In Field research in ujamaa villages, Department of Sociology, University of Dar es Salaam, 1975 .

170. NDONDE, E. C. "Litowa." In Rural cooperation in Tanzania, edited by Lionel Cliffe, e t al., pp. 360-369. Dar es Salaam: TPH, 1975. Most, though not all, of the interview published in this article appeared in "The graduate peasant," New internationalist (May 1973), pp. 19-21.

171. NGOYANI, J. D. "Lupembe ujamaa village as an organization." Student paper, Department of Sociology, University of Dar es Salaam, 1973. 22 p. Cited in Sheldon Weeks, "Building Ujamaa" (Item no. 406). 
172. NKHOIA, A. G. and N. P. DABANA "Segera ujamaa village, Handeni district, Tanga region." Student paper, Department of Sociology, University of Dar es Salaam, 1974. 33 p. In Field research in Tanga ujamaa villages. Department of Sociology, University of Dar es Salaam, 1975.

173. NTAWATAWA, P. P.; J. MWANASAL and J. MUTALEMWA "A study of Mtanana ujamaa village." Student paper, Institute of Adult Education, University of Dar es Salaam, 1972. 4 p.

174. ODEDE, S. O. "Some notes on Tanzania rural development strategy: a case of vijiji vya ujamaa of Tanga region." In strategies for improving rural welfare, proceedings of a workshop held at the Institute for Development Studies, University of Nairobi, 31 May - 3 June 1971, edited by M.E. Kampe and L.D. Smith, pp. 299-309. (Occasional Paper no. 4). Institute for Development Studies, University of Nairobi, 1971.

175. PHILIPPSON, G. "Sociological report on some ujamaa villages in Njombe district." Department of Sociology, University of Dar es Salaam, November 1972. 20 p.

176. PHILliPPS, STEPHANIE H. "Perspectives on ujamaa and rural development in Tanzania." B.A. honors thesis, Department of Economics, Harvard University, March 1973. 86 p.

177. "Postscript to Mbambara 1972." In Rural cooperation in Tanzania, edited by Lionel Cliffe, et al., pp. 392-395. Dar es Salaam: TPH, 1975.

178. "The Prospects for ujamaa transformation in Bagamoyo district." 23 p. In A collection of essays on ujamaa villages, by E.O. Kayombo, etal. Four student dissertations, Department of Political Science, University of Dar es Salaam, 1971.

179. RALD, JORGEN. "U jamaa villages in West Lake region. " Journal of the Geographical Association of Tanzania, no. 6 (1970): 65-81.

180. RIYAMI, ABDULLA. "Litowa village of ujamaa." African development, January 1969, pp. 8-10.

181. RUGIMBANA, R. O. B. and G. G. MPONGULIANA. "On the practical problems in the development of ujamaa villages: Ubiri (case study)." Student paper, Department of Sociology, University of Dar es Salaam, 1974. 18 p. In Field research in Tanga ujamaa villages, Department of Sociology, University of Dar es Salaam, 1975 .

182. WAWERU, E. M. "Itiga ujamaa village: proposals for organizational changes necessary to increase efficiency and effectiveness and minimize forces blocking the achievement of the village's goals." Student paper, Department of Sociology, University of Dar es Salaam, 1973.

183. WENNER, KATE. Shamba letu. [Our farm]. Boston: Houghton Mifflin, 1970. 256 p.

184. WISNER, BEN; MAHINDO KASSAMI and ADONIA NUWAGABA "Mbambara: the long road to ujamaa." In Rural cooperation in Tanzania, edited by Lionel Cliffe, et al., pp. 370-391. Dar es Salaam: TPH, 1975. Based on research done prior to, or in, 1971. 


\section{Role of the government/party}

185. BABYEGEYA, W. B. M. "Extension methods in ujamaa villages and the role of farmers training centers: a comment." In Agricultural extension in ujamaa village development: papers and proceedings of a workshop, edited by Hermann Hansel, et al., pp. 181-183. Morogoro: University of Dar es Salaam, 1975.

186. COULSON, ANDREW. "The evolution of $\mathrm{rural}$ policies in Tanzania or can a government bureaucracy bring about development?" Paper presented at an ERB seminar, University of Dar es Salaam, 21 January 1975. 19 p. Published in Maji Maji, no. 20 (1975): 1-16 and portions of it were published as "Peasants and bureaucrats." Review of African political economy, no. 3 $(1975)$ : $53-58$.

187. DE VRIES, JAMES. "Agricultural extension and the development of ujamaa villages in Tanzania: problems of institutional change." Paper presented at the international conference on adult education, University of Dar es Salaam, June 1976. 24 p. Published as "Agricultural extension and development: ujamaa villages and the problems of institutional change," Community development journal 13, no. 1 (1978) : 11-19.

188. DE VRIES, JAMES. "Agricultural extension and the development of ujamaa villages in Tanzania: toward a dialogical agricultural extension model." Ph.D. dissertation, University of Wisconsin-Madison, 1978. 263 p.

189. DE VRTES, JAMES. "Extension methods in the ujamaa setting: a comment." In Agricultural extension in ujamaa village development: papers and proceedings of a workshop, edited by Hermann Hansel, et al., pp. 184-192. Morogoro: University of Dar es Salaam, $19 \overline{975 .}$

190. ERVES, S. "Final report: evaluation of extension service in six villages in Tanzania participating in the national maize project." Dar es Salaam: USAID/Tanzania, 1976. Cited in James De Vries, Selected bibliography on agricultural extension in Tanzania (Item no. 478).

191. FREYHOLD, K. VON. "The role of agricultural extension in ujamaa village development." In Agricultural extension in ujamaa village development: papers and proceedings of a workshop, edited by Hermann Hansel, etal., pp. 84-93. Morogoro: University of Dar es Salaam, 1975 .

192. FREYHOLD, MICHAELA VON. "The government staff and ujamaa villages (The Tanga experience)." Paper presented at the East African Universities social science conference, Dar es Salaam, December 1973. 17 p. Prepared January 1972.

193. FREYHOLD, MICHAELA VON. "Problems of extension evaluation." In Agricultural extension in ujamaa village development: papers and proceedings of a workshop, edited by Hermann Hansel, et al., pp. 242-262. Morogoro: University of Dar es Salaam, $\overline{19} 75$.

194. HANSEL, H. "New emphasis on extension evaluation in ujamaa villages: a comment." In Agricultural extension in ujamaa village development: papers and proceedinqs of a workshop, edited by Hermann Hansel, e t al., pp. 271-278. Morogoro: University of Dar es Salaam, $1 \overline{975 .}$ 
195. HANSEL, H.; J. DE VRIES and P. C. NDEDYA, eds. Agricultural extension in ujamaa village development: papers and proceeding of a workshop. Morogoro: Department of Rural Economy and Extension, Faculty of Agriculture and Forestry, University of Dar es Salaam, 1975. 292 p. In addition to the papers and the comments on those papers, each of the six sections contains a summary of discussions. A general summary of recommendations is included a the beginning of the volume.

196. HARRIS BELL. "Survey of agricultural training institutes: implications for producing ujamaa vijijini extension workers." (Rural Development Research Committee paper No. 2). Rural Development Research Committee, University of Dar es Salaam, 1968. Cited in James De Vries, Selected bibliography on agricultural extension in Tanzania (Item no. 478).

197. "Historia ya kutoa zawadi kwa vijiji vilivyoshinda." [History of the awarding of prizes for the winning villages]. Ujamaa, no. $26(1972)=7-17$.

198. "Historia na maendeleo ya vijiji vilivyoshinda mwaka 1972." [History and development of the winning villages in 1972]. Ujamaa, no. 26 (1972): $18-39$.

199. HULLS, R. H. "The scope of extension programme evaluation: a comment." In Agricultural extension in ujamaa villaqe development: papers and proceedings of a workshop, edited by Hermann Hansel, et a 1., pp. 279-287. Morogoro: University of Dar es Salaam, 1975.

200. "Impact and penetration of community development activities in rural Dodoma district." 33 p. In A collection of essays on ujamaa villages by E. O. Kayombo, etal. Fourstudent dissertations, Department of Political Science, University of Dar e s Salaam, 1971.

201 KAJIAGE, F. K. "One village, one bwana shamba: its implications." Paper presented at the annual agricultural training conference, Mbeya, July 1976. Cited in James De Vries, Selected bibliography on agricultural extension in Tanzania (Item no. 478).

202. KAWAWA, RASHIDI. Kuandikishwa kwa vijiji, vijiji vya u jamaa na uongczi wake. [Registration of villages, ujamaa villages and their organization:. [Dar es Salaam]: 1975716 p. Slightly revised, and published as Madaraka vijijini: taarifa ya waziri mkuu na makamu wa pili wa rais, juu ya sheria ya vijiji, vijiji vya ujamaa na uongozi wake (Dodoma: Ofisi ya waziri inkuu na Makamu wa Pili wa Rais, 1975), 19 p; and reprinted in Tanzania, Idara ya Maendeleo ya Uiamaa na Ushirika, ofisi ya Waziri Mkuu na Kakamu wa Pili wa Rais, Sheria ya kuandikisha vijiji navijiji vya ujamaa (Dodoma: Ofisi ya Waziri Mkuu na Makamu wa Pili wa Rais, 1975), pp. 3-21.

203. KHARUMO, C. G. "Extension staff to serve the chansins needs of villages." In Agricultural extension in ujamaa village development: papers and proceedings of a workshop, edited by Hermann Hansel, et al., pp. 217-220. Morogoro: University of Dar es Salaam. $19 \overline{975 .}$

204. KREUTZER, H. "Unified agricultural production planning: a comment." In Agricultural extension in ujamaa village development: papers and proceedings of a workshop, edited by Hermann Hansel, et al., pp. 140-141. Morogoro: University of Dar es Salaam, 1975. 
205. MABELE, R. B. "Extension programme development and a aricultural production planning. "In Agricultural extension in ujamaa village development: papers and proceedings of a workshop, edited by Hermann Hansel, et al., pp. 107-132. Morogoro: University of Dar es Salaam, 1975.

206. Mapendekezo juu ya kuimarisha vyama vya ushirika Tanzania (Bara) na mundo mpya wa vyama pamoja na chama kikuu cha taifa (C. U.T.). [Preferences concerning the strengthening of cooperative societies on the Tanzania (mainland) and the new union of societies and the cooperative union of Tanganyika. [Dar es Salaam: CUT, 1977 ]. 14 p.

207. MBAKILE, E. P. R. "Evaluation to strenathen the extension svstem: a comment." In Agricultural extension in ujamaa village development: papers and proceedings of a workshop, edited by Hermann Hansel, e t al., pp. 263-270. Morogoro: University of Dar es Salaam, $1 \overline{975 .}$

208. MFIKWA, J. L. "The role of essential agricultural services in the economic development of ujamaa villages in Ismani division, Iringa district." Paper prepared for the Department of Rural Economy, University of Dar es Salaam, Morogoro, 1975. Typescript. 53 p. Cited in Ibrahim B. Kai-Samba, et al., Development for self-reliance (Item no. 480).

209. MONGI, L. M. "New trends in training extension cadres: a comment." TA Agricultural extension in ujamaa village development: proceedings of a workshop, edited by Hermann Hansel, et al., pp. 211-216. Morogoro: University of Dar es Salaam, 1975.

210. MORIS, JON R. "The improvement of extension performance: staff and farmer training: a comment." In Agricultural extension in ujamaa village development: proceedings of a workshop, edited by Hermann Hansel, etal., pp. 221-238. Morogoro: University of Dar es Salaam, 1975.

211. HOSHA, A. C. and K. J. RWIZA. "Training extension staff and ujamaa villages." In Agricultural extension in ujamaa village development: papers and proceedings of a workshop, edited by Hermann Hansel, etal., pp. 196-210. Morogoro: University of Dar es Salaam, 1975.

212. NDEDYA, PHILIP C. "A-qricultural extension in uiamaa village: a comment." In Agricultural extension in ujamaa village development: papers and proceedings of a workshop, edited by Hermann Hansel, et al., pp. 98-102. Morogoro: University of Dar e s Salaam, $19 \overline{75 .}$

213. NDONDE, E. C. "Educational Methods for Self-Reliant Development. " In Agricultural extension in ujamaa village development: papers and proceedings of a workshop, edited by Hermann Hansel, e t a 1., pp. 164-180. Morogoro: University of Dar es Salaam, 1975 .

214. NEIGUS, D. L. "Extension and village organization: a comment. " In Agricultural extension in ujamaa village development: papers and proceedings of a workshop, edited by Hermann Hansel, e t a 1., pp. 94-97. Morogoro: University of Dar es Salaam, 1975 . 
215. NGEZE, P. B. N. M. "On staff constraints in planning: a comment." In Agricultural extension in ujamaa village development: papers and proceedings of a workshop, edited by Hermann Hansel, e t a l., pp. 133-139. Morogoro: University of Dar es Salaam, 1975 .

216. NGEZE, P. B. N. M. "Vijij i vya ujamaa na muundo mpya wa ryama vya ushirika." [Ujamaa villages and the new form of cooperative societies]. In Ushirika Tanzania by P.B.N.M. Ngeze, pp. 113-123. Dar es Salaam: TPH, 1975.

217. NSEREKO. J. "Methods of extension programme develooment: a comment." In Agricultural extension in ujamaa village development: papers and proceedings of a workshop, edited by Hermann Hansel, \&\&., pp. 151-160. Moroqoro: University of Dar es Salaam, 1975.

218. OKEYO, JAMES A. "Discussion paper on village Management Training Programme: a crash programme for ujamaa and cooperative development personnel in the Prime Minister's office." In Proceedings of the second annual meeting of the National Councilfor Agricultural Education held at the Uyole Agricultura 1 Center, Mbeya, July 1976, pp. 17-21. Mbeya: Uyole Agricultural Center, 1976 ?

219. OLIECH, Y. K. C. "Comprehensive, integrated village planning and the role of adult education: a comment." In Agricultural extension in ujamaa village development: papers and proceedings of a workshop, edited by Hermann Hansel, et. al., pp. 142-150. Morogoro: University of Dar es Salaam, 1975.

220. RWIZA, K. J. "An aqricultural technician for each village." In Proceedings of-the second annual meeting of the National Council for Agricultural Education held at the Uyole Agricultural Center, Mbeya, July 1976, pp. 4-7. Mbeya: Uyole Agricultural Centre, 1976?

221. "Saidi Mwamwindi versus Republic, case no. 212." Tanzania high court digest 6 no. 5 (1972): 244-261.

222. SANGA, L. B. "Training experience of village Management Training Programme." National Council of Agricultural Education conference, Tengeru, August 1977. Cited in James De Vries, $\mathbf{E}$ lected bibliography on agricultural extension in Tanzania (Item no. 478).

223. Semina ya mameneja wa vyama vikuu vya ushirika, halmashauri na wajumbe wa CUT iliy of anyika tarehe $28 / 8 / 1975-30 / 8 / 1975$, mini Dar es Salaam. \{A seminar of managers of cooperative unions, executive committee of CT which was held 28-30 August 1975, Dar es Salaam]. [Dar es Salaam]: Cooperative Union of Tanganyika, n.d. 107 p.

224. TANU. Taarifa ya tume maalum iliyokwenda mkoa wa Ziwa Magharibi Kusikiliza matatizo juu ya wabunge wa mkoa huo na mkuu wa mkoa huo. [The report of the special commission which went to West Lake Region to investigate the troubles between the M.P.s and the regional commissioner of the region]. Dar es Salaam: Government Printer, 1968. 79 p.

225. TANZANIA. MARKETING DEVELOPMENT BUREAU. Expansion of village agricultural extension services: preliminary paper for is cussion. Dar es Salaam Marketing Development Bureau, Ministry of Agriculture, 1976. 42 p. 
226. TANZANIA. MARKETING DEVELOPMENT BUREAU. Expansion of village level training facilities: preliminary paper for discussion. Dar es Salaam: Ministry of Agriculture, 1976. 34 p.

227. TANZANIA. VILLAGE MANAGEMENT TRAINING PROGRAMME Publications. Dar es Salaam: Village Management Training Programme, Prime Minister's Office, 1976-1977. In Swahili or English titles include: Case studies adopted to the VMT-training (40 p.); Cooperative management and law (34 p.); Crop storage (9 p.); Instruction on collection and utilization of village data (10 p.); Kazi za V.M.T. (miezi 6 ya mwanzo) pamoja na utaratibu wa kutoaripoti, [V.M.T. work (the first 6 months) together with its system of reporting] ( 6 p.); Mafunzo ya uongozivijijini, [A course on village leadership] (33 p.); Management (67 p.); Measomo ya Kilimo Kua VMIT, [Lessons in agriculture for VIMT (59 p.); Teacher's manual: orientation course (42 p.); Utangulizi wa hesabu za biashara, [Basic course in commercial arithmetic] (56 p.); Village planning (63 p.); Villaqe planninq and budgeting (76 p.); Village training $(42 \mathrm{p}$.$) ; Village transport and storage (63 p.);$ Tamm, Robert, Village transport and tractorisation: guidelines for feasibility studies $(2$ p.); Tamm, Robert, Village transport operations $(54 \mathrm{p}$.$) ; Agricultural marketing in villa-$ ges ( l p.); and Kitabu cha mwonqozo wa uhasibu na utunzaji wa vitabu vya hesabu vijijini, [A study guide in accounting and maintaining account books in the villages] (219 p.). A 11 the above were cited in the Library of Congress Accessions List, Eastern Africa, during 1977.

228. VERHAGEN, KOENRAD. "La nouvelle politique de développement rural en Tanzanie (1975-1978)." [New politics of rural development i n Tanzania (1975-1978)]." Revue des études coopératives, no. 197 (1979): 105-113.

229. Vijiji vilivyoshinda, Safoa Saba 1975. [Winning villages, Saba, Saba 1975]. [Dodoma]: Makao Makuu ya TANU na Ofisi ya Waziri Mkuu na Makamu wa Pili wa Rais, 1975? 22 p. At least two other pamphlets with similar titles were published prior to this one: Tanzania. Ofisi va Waziri Mkuu na Makamu wa Pili wa Rais, Vijiji vya ujamaa vilivyoshinda: TANU maka 20 Saba Saba 1974 (Dar es Salaam: Ofisi ya Waziri Mkuu, 1974), 26 p. and; Tanzania, Idara ya Vijiji vya Ujamaa, Vijiji vya ujamaa vilivyoshinda - Saba Saba 1972 (Dar es Salaam: Idara ya Vijiji vya Ujamaa, 1972), 35 p.

230. WANACHUO, CHUO CHA CCM (Kivukoni). "Kupeleka wataalam na madaraka vijijini kama mbinu ya kuleta maendeleo. "[Sending development experts to villages as a force to bring development]. Ujamaa, no. 56 (1978): $1-28$.

3. Agricultural activities

231. ASSEY, G. A. "The organizational pattern and production efficiency of communal vegetable farms: a case study of Monjo ujamaa village in Lushoto district." Special project for B. Sc. (Agriculture), Rural Economy Department, University of Dar es Salaam, Morogoro, 1974. 41 p. Cited in Ibrahim B. KaiSamba et.al., Development for self-reliance (Item no. 480).

232. BAIDUS, R. D. "The introduction of cooperative livestock husbandry in Tanzania." Land reform 2 (1977): 37-46. 
233. "Bedingungen Moglichkeiten nachholender Entwicklung: eine Empirische Untersuchung zu Problemen Traditionaler Produktionswesen und Ihrer Überwindung durch Politische Mobilisierung und Sozial-okonomische Transformationen am Beispiel der Ujamaa Strategie in Tanzania." [Conditions and potentialities of achieving development: an empirical investigation into the problems of traditional modes of production and of surmounting them through political mobilization and socialeconomic transformation: the example of the ujamaa strategy in Tanzania]. Frankfurt am Main: Institut fur Sozialforschung an der Johann Wolfgang Goethe Universitat, 1972. 29 p. Cited i n Volkhard Hundsdorfer and Wolfgang Kuper, Bibliographie zur Sozialwissenschaftliqen Erforschung Tanzanias (Item no. 479).

234. BOESEN, JANNIK and A. T. MOHELE. The 'sucess story' of peasant tobac'co production in Tanzania. (Centre for Development Research, publication No. 2). Uppsala: Scandinavian Institute of African Studies, 1980.

235. "Conditions and possibilities for overcoming underdevelopment: an empirical investigation into the problems of traditional modes of production and of surmounting them by means of political mobilization and socio-economic transformation: using the example of the ujamaa strategy in Tanzania." Frankfurt am Main: Institut fur Sozialforschung an der Johann Wolfgang Goethe Universität, 1972. 281 p. Cited in Volkhard Hundsdörfer and Wolfgang Kuper, Bibliographie zur Sozialwissenschaftlichen Erforschung Tanzanias (Item 479).

236. DAVIDSSON, JAN. Some basic guidelimes for village transport operation in combination with cultivation. [Dar es Salaam ]: Transport Section, Ujamaa and Cooperative Development Department, Prime Minister's Office, January 1976. 30 p.

237. DUE, JEAN M. "Agricultural credit in Tanzania." (Illinois Agricultural Economics Staff paper no. 77 E-2). Department of Agricultural Economics, University of ItIinois a UrbanaChampaign, March 1977. 19 p. Published in Journal of southern African affairs 3, no. 1 (1978): 99-113.

238. DUE, JEAN M. "Agricultural credit in Tanzania, part III." (I11inois Agricultural Economics Staff paper no. 78 E-38). Department of Agricultural Economics, University of Illinois a t Urbana-Champaign, 1978. $32 \mathrm{p}$.

239. DUE, JEAN M. "The allocation of credit to small farmers in Tanzania and Zambia." (Illinois Agricultural Economics Staff paper no. 78 E-55). Department of Agricultural Economics, University of Illinois at Urbana-Champaign, 1978. $28 \mathrm{p}$.

240. DUE, JEAN M. "The allocation of credit to ujamaa villages and to small private farmers in Tanzania." Paper presented at the annual meeting of the African Studies Association, Houston, Texas, November 1977. 28 p. Published in Savings and development 2 (1978): 69-107.

241. DUE, JEAN M. Costs, returns and repayment experience of ujamaa villages in Tanzania 1973-1976. Washington, D.C.: University Press of American, 1980. 141 p. Summary of her Staff Papers I, II and III nos. 237, 242, 238). 
242. DUE, JEAN M. and WAYE MILLER. "Agricultural credit in Tanzania, part II." (Illinois Agricultural Economics Staff Paper No.

77 E-15). Department of Agricultural Economics, University of Illinois at Urbana-Champaign, July 1977. 121 p.

243. JAMES, R. W. Land tenure and policy in Tanzania. Nairobi: EALB, 1971. 375 p. Part IV on Collective Tenure is relevant. pp. $225-258$.

244. KIRO, D. J. B. "A study of the feasibility of rural training centre acting as an input producing and marketing agent for ujamaa villages." Special project, B. Sc. (Agriculture), Department of Rural Economy, University of Dar es Salaam, Moroqoro, 1974. Typescript. 67 p. Cited in Ibrahim B. KaiSamba, et al., Development for self-reliance (Item no. 480).

245. KROKFORS, CHRISTER. "Agricultural development in selected ujamaa villages in Sumbawanga district." (BRALUP research report 4/1). University of Dar es Salaam, January 1973. 34 p.

246. LAWRENCE, PETER R. "Sisal: the case for ujamaa production." In Rural cooperation in Tanzania, edited by Lionel Cliffe, et al., pp. 480-505. Dar es Salaam: TPH, 1975.

247. LUPATU, M. A. "Analysis of egg production and marketing problems in ujamaa villages in Morogoro district." Student paper, Department of Animal Science, University of Dar es Salaam, Morogoro, 1975. Typescript. 43 p. Cited in Ibrahim B. KaiSamba, etal., Development for self-reliance (Item no. 480)

248. MACHUNDA, J. B. "Dairy development potential under ujamaa villages: a case study of five districts." Paper presented at the fourth scientific conference of the Tanzanian Society of Animal Production held at Mbeya, May 1977. 4 p. Cited in Ibrahim B. Kai-Samba, et al., Development for self-reliance (Item no. 480).

249. MKONGWA, A. G. "Tobacco production in ujamaa villages in Iringa district." Special Project, Faculty of Agriculture and Forestry, University of Dar es Salaam, 1975. Cited in James De Vrics, "Agricultural extension and the development at Ujamaa villages in Tanzania" (no. 187).

250. MOHELE, A. T. "The Ismani maize credit programme." (ERB paper 75.2). University of Dar es Salaam, 1975. 39 p. Published in Kwan S. Kim, Robert B. Mabele and Michael J. Schulthesis, eds., Papers on the political economy of Tanzania (Nairobi: Heinemann, 1979), pp. 216-222.

251. MSAMBICHAKA, L. A. "Agricultural mechanization in ujamaa villages: prospects and problems." (ERB paper 75.7). University of Dar es Salaam, 1975. 43 p.

252. MSAMBICHAKA, L. A. and ROBERT B. M. MABELE. "Agricultural credit and the development of ujamaa villages in Tanzania." (ERB paper 74.10). University of Dar es Salaam, 1974, 40 p. Published in the Journal of economic reflections (journal of the Economic Association, University of Dar es Salaam), no. 3 (1974): 32-58; republished in Kwan S. Kim, Robert B. Mabele and Michael J. Schulthesis, eds., Papers on the political economy of Tanzania (Nairobi: Heinemann, 1979), pp. $207-215$. 
253. MSHISENI, K. E. "Seaweed faming: a possibility for Tanzania's coastal ujamaa villages." Tanzania notes and records 79/80 (1976): 99-105.

254. MUSSULA, J. T. "Nansio beach fishing research project." 10 p. In Ujamaa villages: a collection of original manuscripts, 1969-70, Tanzania Ministry of Commity Development. A manuscript collected by Eugene de Benko, Michigan State University, March 1971, in Dar es Salaam.

255. MVENA, Z. S. K. "Problems of tobacco production in Iringa: a case study of Kiwere ujamaa village." Special project, B. Sc. (Agriculture), Department of Rural Economy, University of Dar es Salaam, Morogoro, 1977. 87 p. Cited i n Ibrahirn B. Kai-Samba, et al., Development for self-reliance (no. 480).

256. NDISSI, CHACHA. "Ujamaa villages as a collective development strategy in Tanzania's economic development." Ph.D. dissertation, George Washington University, 1976. 154 p.

257. NGEZE, P. B. N. M. "Some aspects of agricultural development in ujamaa villages." Paper presented at the East African Agricultural Economic Society ccnference, University of Dar es Salaam, June 1973. 20 p.

258. NIINIVAAR, MARJATTA. "Ujamaa villages and communal agricultural production." Master's thesis, Department of Economics, University of Dar es Salaam, 1974. 49 D.

259. RAIKES, PHILIP L. "Wheat and ujamaa villages." In Rural cooperation in Tanzania, edited by Lionel Cliffe, et al., pp. 455479. Dar es Salaam: TPH, 1975.

260. RUGUMISA, S. and C. T. BARNES. "'Rural development finance:' a critique of conventional assumptions and a consideration of alternative approaches in a transition to socialist economy with special reference to Tanzania." (ERB seminar paper). University of Dar es Salaam, September 1974. 46 p.

261. SEUSHI, I. and J. LOXLEY. "Financing uiamaa: s tat e resources and cooperative development." In Rural cooperation in Tanzania, edited by Lionel Cliffe, e etal., pp.538-554. Dar es Salaam: TPH, 1975.

262. SHARMA, A. C. "Economy of ujamaa and individual shambas in Iringa region." Department of Rural Economy, University of Dar es Salaam, Morogoro, 1974. 94 p. Cited in Ibrahim B. Kai-Samba, e t a l., Development for self-reliance (no.480).

263. SHARMA, RAVINDRA D. "Agro-economic surveys in some ujamaa villages." Paper prepared at the Research and Training Institute, Ministry of Agriculture, Food and Cooperatives, Ukiriguru, March 1971. $30 \mathrm{p}$.

264. SHARMA, RAVINDRA D. "Man-power utilization in ujamaa villages." Paper prepared at the Research and Training Institute, Ministry of Agriculture, Food and Cooperatives, Ukiriguru, 1971? $11 \mathrm{p}$.

265. SUMRA, SULEMAN. "Problems of agricultural production in ujamaa villages in Handeni district." (ERB paper 75.3). University of Dar es Salaam, 1975. 19 p. Reprinted in Kwan S. Kim, Robert B. Mabele and Micahel J. Schultheis, eds., Papers on the political economy of Tanzania (Nairobi: Heinemann, 1979), pp. 202-206. 
266. "Transformation oder Mobilisierung als Anreiz sur Veränderung der Produktionsweisen, am Beispiel von 'settlements' und 'Ujamaa-Dörfern' in Tanzania." [Transformation or mobilization as incentive for changing modes of production, an example of 'settlements' and 'ujamaa-villages' in Tanzania]. Frankfurt am Main: Institut fur Sozialforschung an der Johann Wolfaana Goethe Universitat. 1970. 160 p. Cited in Volkhard Hundsdörfer and Wolfgang Küper, Bibliographie zur Sozialwissenschaftlichen Erforschung Tansanias (Item no. 479)

267. TRAORE, ALY. "Rapports agriculture-industrie et 'Socialisme ujamá' en Tanzanie." [Reports on agriculture-industry and

'ujamaa socialism' in Tanzania]. Revue tiers-monde 16 no. 64 (1975): 805-320.

268. ULVUND, K. A. and G. I. MKINDI. An agro-economic study in Ufipa Plateau. (Research report no. 19). Mbeya: Uyole Agricultural Centre, 1976. 112 p. Part 4, "The ujamaa village survey" is relevant, pp. 69-90.

269. VAIL, DAVID J. "The intracontinental transfer of intermediate technology designed for Tanzania's ujamaa villages.' 'Paper presented at the annual meeting of the African Studies Association, Chicago, November 1974. 26 p.

270. VAIL, DAVID J. Technology for ujamaa village development in Tanzania. Syracuse, New York: Maxwell School of Citizenship and Public Affairs, Syracuse University, 1975. 64 p.

\section{Non-agricultural activities}

271. AMANI, M. "A national plan for library development in ujamaa villages of Tanzania." Someni 6, no. 1 (1975): 20-23.

272. BOALT, C. Village housing in Tanzania: a pilot study of four villages in transition. (Working report no. 4). Dar es Salaam: National Housing and Building Research Unit, Ministry of Lands, Housing and Urban Development, March 1975. 254 p.

273. CHUO CHA ELIMU YA USHIRIKA. "Vijiji vya ujamaa: mafunzo maalum kwa vikundi vya kujifunza." [ujamaa villages: special lessons for study groups]. Moshi: Chuo Cha Ushirika, 1972. 27 p.

274. COMMUNITY DEVELOPMENT TRUST FUND OF TANZANIA. Appropriate technology for grain storage in Tanzanian villages, report of a pilot project, January, 1977. New Haven, Conn.: Economic Development Bureau, 1977. $94 \mathrm{p}$.

275. COOPERATIVE UNION OF TANGANYIKA. Cooperative Education Centre. Ujamaa vijijini. Moshi: Cooperative Union of Tanzania, 1967+? Contains Guidelines and five pamphlets as follows: no.I "Masharti ya ujamaa." The statutes of ujamaa].1970, $13 \mathrm{p}$.

no.2 "Muundo wa kijiji cha ujamaa." [The structure of ujamaa villages]. 1970, $13 \mathrm{p}$.

no.3 "Uongozi wa kijiji cha ujamaa." [Leadership of Ujamaa Villages.]. 1970, $12 \mathrm{p}$.

no.4 "Maendeleo ya Kijiji." [The Development of a Village]. $1971,9 \mathrm{p}$.

no.5 "Uchumi wa Kijiji." [The Economy of a Village;. 1971, 13 p. Guidelines cited in Printed in Tanzania, 1971. 
276. GOTTLIEB, MANUEL. "Health survey of selected households, rural and urban, mainland Tanzania, six districts, summer 1972." (ERB paper 74.1). University of Dar es Salaam, 1974. 47 p.

277. INSTITUTE OF ADULT EDUCATION. UNIVERSITY OF DAR ES SALAAM. Matunda ya kuishi kijamaa. [Fruits of an ujamaa life]. Nairobi: EALB, 1971. 21 p.

278. KAHAMA, C. G. "Promotion of small-scale industries in ujamaa villages." Mbioni 7, no. 2 (1973): 5-26.

279. KAzimoto, A. A. "Planning implications of the policy of ujamaa villages." Mbioni 6, no. 6 (1971): 15-21.

280. LEWIN, ROGER. "Education in the ujamaa village." Mbioni, no. 8 (1968): 8-16. Published in Swahili as "Elimu katika kijiji cha ujamaa," Ujamaa, no. 6 (1968): 31-42.

281. LEWIN, ROGER. "Tatizo la ujamaa vijijini - uchawi: sehemu ya I." [A problem of ujamaa villages - witchcraft: part I]. Ujamaa, no. 4 (1968): 30-33. Part II should be in Ujamaa, no. 5.

282. LONG, NORMAN. "Cooaerative enterorise and rural develonment in Tanzania." In Rural cooperatives and planned changk in Africa, case materials, edited by Raymond Apthorpe, pp. 287-361. Geneva: United Nations Research Institute for Social Development, 1970 .

283. MARO, PAUL S. and WILFRED F. I. MLAY. "Decentralization and the organization of space in Tanzania." Africa 49, no. 3 (1979): $291-301$.

284. MASON, ALAN. "Education for ujamaa living." Mbioni 4, no. 11 (1968): 26-34.

285. MBENNA, IRENEI CASSIAN. Ujamaa siuwezi. [communal living is impossible]. Dar es Salaam: Maarifa Publishers, 1973. 25 p. Cited in the Library of Congress, Accesions List, Eastern Africa 10, no. 3 (1977) is a possible reprint titled Siuwezi ujamaa (Dar es Salaam: EAPH, 1976), 22p.

286. MWAKISYOMBE, J. S. E. "Matatizo ya uwekaji na ufunzaji wa kumbukumbo za inahesabu ya biashara katika vijıjı vya ujamaa na vyama vya usnirika. [Problems of preparing and keeping accounts in ujamaa villages anà cooperative societies]. Ujamaa, no. 34 (1974): 16-28.

287. MWASE, NGILA R.L. "Cooperatives and ujamaa in Tanzania: a case study of the Arusha Region Cooperative Union Limited (ARCU)." Student dissertation, Department of Political Science, University of Dar es Salaam, March 1973. 135 p. Preliminary version published in Economic reflections (journal of the Dar es Salaam University Economics Association) 1 (1972): 27-31; and published in a substantially cut form as "Cooperatives and ujamaa: a case study of the Arusha Region Cooperative Union Limited (A.R.C.U.) " in Göran Hyden, ed., Cooperatives in Tanzania (Dar es Salaam: TPH, 1976), pp. 78-93.

288. MWOLEKA, CHRISTOPHER and JOSEPH HEALEY, eds. Ujamaa and Christian communities. Eldoret, Kenya: Gaba Publications, Amecea Pastoral Institute, 1976. 63 p. 
289. "NDC Goes to the Villages." Jenga, no. II (1972): 14-19.

290. NG'WANDU, PIUS YASEBASI. "The role of adult education in meeting the development needs of ujamaa villages in Tanzania." Master's thesis, University of Alberta, Edmonton, Alberta, 1973.

291 NG'WANDU, PIUS YASEBASI. "Ujamaa villages: Tanzania's strategy versus rural underdevelopment, and the role of adult education." (Studies in adult education no. 15). Institute of Adult Education, University of Dar es Salaam, 1974. 40 p.

292. NIEUWENHOVE, JACQUES VAN. "Presence Chretienne en societe socialiste, valeur pastorale d'une integration dans les villages uiamaa." [Christian presence in socialist society, the value of pastoral integration with ujamaa villages]. In Socialisme et Eglise en Tanzanie by $\mathbf{s}$. Urfer, pp. 107-128. Paris: IDOCFrance. 1975. Abridsed and translated into Enslish in Marilee Karl, ed., Ujamaa and self-reliance: building socialism in Tanzania (Rome: IDOC, 1976), pp. 69-73.

293. NSHIKU, T. "Vijiji vya ujamaa." [Ujamaa villages]. In Tanzania kabla na baada ya uhuru, edited by the Institute of Adult Education, University of Dar es Salaam, pp. 70-81. Kampala: EALB, 1971.

294. NYERERE, JULIUS K. Ujamaa ni imani 3: kufanya kazi pamoja. [Socialism is faith 3: working together]. Dar es Salaam: EAPH, 1974. 43 p.

295. NYERERE, JULIUS K. Ujamaa ni imani 1: moyo kabla ya silaha. [Socialism is faith I: the heart before the weapon]. Dar es Salaam: EAPH, 1973, 72 p.

296. OMARI, C. K. and E. A. LUKWARO. "Settlement patterns and ujamaa," Tanzania notes and records, no. 83 (1978): 21-28.

297. "Planning for nutritional self-sufficiency for ujamaa villages in the context of Tanzania's goals for national development." In Nutritional planning and policy for African countries: summary report of a seminar held in Nairobi, Kenya, June 1976, edited by Micahel Latham and Sidney Westley, pp. $\overline{78}^{7} 6$. (Occasional paper no. 21). Institute for Development Studies, University of Nairobi, 1976. Republished as Cornell international nutrition monograph series no. 5 by the Cornell University Program on International Nutrition and Development Policy, Ithaca, New York, 1977, pp. 63-73.

298. RAIKES, PHILIP L. "Village planning for ujamaa." Taamuli 3, no. I $(1972): 3-26$.

299. RUPIA, J. A. J. "Mpango wa uchumi wa kijiji cha ujamaa." [Economic plan for an ujamaa village]." Ujamaa, no. 25 (1971?): $7-15$.

300. SHIMBA, H. J. M. "Socio-economic conditions of ujamaa introduction in Handeni district." Special project, B.Sc. (Agriculture), Rural Economy Department, University of Dar es Salaam, Morogoro, n.d. 46 p. Cited in Ibrahim B. Kai-Samba, et al., Development for self-reliance (no. 480).

301. TANU. Maisha ya ujamaa. The ujamaa life. Dar es Salaam: Makao Makuu ya TANU, 1971? 40 p. 
302. TANU. Vijiji vya ujamaa, vitabu vya darubini 2. [ujamaa villages, study books no.2 ]: Dar es Salaam: EAPH, 1971. 64 p.

303. TANZANIA, CHUO CHA ELIMU YA WATU WAZIMA. CHUO KIKUU CHA DAR ES SALAAM. Matunda ya kuishi kijamaa. [ The fruits of socialist living]. Nairobi: EALB 1971. 21 p.

304. TANZANIA. IDARA YA MIPANGO YA UTUMISHI. WIZARA YA MAENDELEO YA UTUMISHI. "Uchunquzi wa mahitaji ya mafunzo ya ufundi/utaalam vijijini." [Research on the requirements for technical education in the villages]." [Dar es Salaam?] : Idara ya Mipango ya Utumishi, Wizara ya Maendeleo ya Utumishi, 1977. $72 \mathrm{p}$.

305. TANZANIA. KAMATI YA KUCHUNGUZA ELIMU YA UJAMAA NA USHIRIKA. Mpango wa elimu ya ujamaa na ushirika, Tanzania, 1973-1979. [The-education plan for ujamaa villages and cooperative societies]. Dodoma. January 1973. 84 p.

306 TANZANIA. NATIONAL HOUSING AND BUILDING RESEARCH UNIT. MINISTRY OF LANDS, HOUSING AND URBAN DEVELOPMENT. Report from a seminar held at Lushoto, February, 1974. Dar es Salaam: Ministry of Lands, Housing and Urban Development, July 1974. $41 \mathrm{p}$.

307. TANZANIA. OFISI YA WAZIRI MKUU NA KAKAMU WA PILI WA RAIS. $\mathbf{V}$ ka ya ujamaa. Ujamaa shops. Dodoma: Ofisi ya Waziri Mkuu na Makamu wa Pili wa Rais, May 1976. 18 p.

308. TANZANIA. UJAMAA AND COOPERATIVE DEVELOPMENT DEPARTMENT. PRIME MINISTER'S OFFICE. A guide for planning, operation and control of a village cooperative shop. [Dodoma], 1974 ? 33 p.

309. TANZANIA. UJAMAA AND COOPERATIVE DEVELOPMENT DEPART-VENT . PRIME MINISTER'S OFFICE. Manual and textbook for village bookkeeping system. Dodoma . 1976? $116 \mathrm{p}$.

310. TANZANIA. UJAMAA AND COOPERATIVE DEVELOPMENT DEPARTMENT. The operational manual of the Tanzania rural savings and credit scheme. Dar es Salaam: Office of the Prime Minister and the Second Vice President, 1976? 59 p.

311. TOROKA, S. "Education for self-reliance; the Litowa experiment." Mbioni 4, no. II (1968): 2-25. Republished in Rural Africana, no. 9 (Fall 1969), pp. 23-33; and in Lionel Cliffe and John Saul, eds., Socialism in Tanzania, Vol. 2 (Dar es Salaam: EAPH, 1973), pp. 264-271.

312. TSCHANNERL, GERHARD. "Rural water supply in Tanzania: is 'politics' or 'technique' in command?" Paper presented at the East African Universities social science conference, Dar es Salaam, December 1973. 33 p. Published in The African review 6, no. 2 (1976) : 165-194.

313. WESTMAN, JOHANNA. "Planning ujamaa." Mbioni 5, no. 7 (1969): $3-9$.

314. WOOD, A. W. "The community school in Tanzania: the experience at Litowa." Teacher education in new countries 10, no. 1 (1969) : 4-12. 
5. Villagers and village leaders

315. BAVU, IMMANUEL. "Leadership and communication in the ujamaa process: a case study of Kabuku-Ndani ujamaa village cooperative society." Master's thesis, Department of Sociology, University of Dar es Salaam, 1971.

316. FORTMANN, LOUISE. "Women's work in a communal setting: the Tanzanian policy of ujamaa." Paper presented at the conference on Women and Work in Africa, University of Illinois, Urbana, Illinois, 29 April - 1 May 1979. 18 p.

317. GUillotte, J. V. "Attitudes toward ujamaa in a multi-ethnic rural community in northern Tanzania." Paper presented at the annual meeting of African Studies Association Syracuse, New York, November 1973. $14 \mathrm{p}$.

318. LEWIN, ROGER. "Jinsi viongozi wa siasa wanavyoweza kuwasaidia wakulima." How political leadership is able to help peasants . Ujamaa, no. 4 (1968): 8-11.

319. LEWIN, ROGER. "On ujamaa villages." Dar es Salaam, n.d. 19 p.

320. MAEDA, JUSTIN HUMPHREY J. "Popular participation, control and development (a study of the nature and role of popular participation in Tanzania's rural development)". Ph.D. dissertation, Department of Political Science, Yale University, 1976. 410 p.

321. MASCARENHAS, ADOLFO C. "Settlements and population redistribution in Dodoma." (BRALUP Research paper no. 47). University of Dar es Salaam, March 1977. 35 p.

322. MASHAURI, R. K. "Leadership structure and communication in an ujamaa village: a case study of Gallu." Student dissertation, Department of Political Science, University of Dar es Salaam. 1970. $14 \mathrm{R}$. Published in slightly revised form in J.H. Procter, ed., Building ujamad villages in Tanzania, (Dar es Salaam: TPH, 1976), pp. 55-63.

323. MCHENRY, DEAN E., JR. "Peasant participation in communal farming: the Tanzanian experience." Paper presented at the annual meeting of the African Studies Association, Boston, November 1976. $31 \mathrm{p}$. Published in slightly revised form in the African studies review 20, no. 3 (1977): 43-63; reprinted in Alan Smith and Claude Welch, eds., Peasants in Africa (Waltham, Massachusetts: Crossroads Press, 1978), pp. 43-63.

324. MCHENRY, DEAN E., JR. "Rural policy divergence: communal farming in ujamaa villages." Paper presented at the East African universities social science conference, University of Nairobi, December 1975. $13 \mathrm{p}$.

325. "Mfano wa katiba ya kijiji cha ujamaa." An example of a constitution of an ujamaa village. In Tanzania kabla na baada ya uhuru, edited by the Institute of Adult Education, University of Dar es Salaam, pp. 111-115. Kampala: EALB, 1971. 
326. MPESHA, M. A. L. "The effect of participation in decisionmaking on commitment to ujamaa work: a case study of Rugaze and Omurunazi ujamaa villages in Bukoba district." Special project, B.Sc. (Agri-culture), Department of Crop Science, University of Dar es Salaam, Morogoro, 1976. 51 p. Cited in Ibrahim B. Kai-Samba, et al., Development for self-reliance (no.480).

327. NDUNGURU, CRESCENT C. "Ujamaa: a comparative study of perceptions and orientation in Kilosa and Mpwapwa Districts." Master's thesis, University of Dar es Salaam, 1973.

328. SENDER, JOHN. "Some preliminary notes on the political economy of rural development in Tanzania based on a case study in the western Usambaras." (ERB paper 74.5). University of Dar es Salaam, May 1974. 59 p.

329. STORGAARD, B. "Women in ujamaa villages." Rural Africana 29 (Winter 1975-76): 135-155.

330. SWANTZ, MARJA-LIISA. "Strain and strenght among peasant women in Tanzania." (BRALUP research paper no. 49). University of Dar es Salaam, 1977. 81 p.

331. SWANTZ, MARJA-LIISA. "Youth and ujamaa development in the Coast region of Tanzania." Paper presented at the East African universities social science conference, Dar es Salaam, December 1973. 28 p. Revised substantially and published as "Youth and development in the coast region of Tanzania" (BRALUP research report no. 6 (new series), University of Dar es Salaam, 1974, 48 p.

\section{Evaluation of the Ujamaa Village Approach to Rural Development}

Many of the studies of ujamaa villages categorized elsewhere in this bibliography contain evaluations of progress and suggestions for improvement. Student papers, influenced by the drive to make education relevant to socialist development, frequently contain sections providing advice for overcoming problems. In this section, though, works whose general theme is evaluative are included. They are of two types: general reviews of the effort, which are implicitly evaluative, and specific assessments of the undertaking, which are explicitly evaluative.

1. Review of the effort

332. Antoniotto, Alberto. "L'esperienza dell'ujamá in Tanzania: una riconsiderazione antropologica." [The experience of ujamaa in Tanzania: an anthropological reconsideration]. Africa 32, no. 2 (1977) : 177-199. 
333. BALDUS, ROLF D. Zur Operationalen Effizienz der Ujamaa Kooperative Tansanias. [The operational efficiency of the ujamaa cooperatives in Tanzania!. Gottingen: Vandenhoeck and Ruprecht, 1976. 275 p. Contains English summary and an extensive bibliography.

334. BARKER, JONATHAN. "Socialism and the rural sector in Tanzania." Paper presented at the American Political Science Association meeting, September 1976, Chicago.31 p. Revised and published under the title "The debate on rural socialism in Tanzania" in Bismarck Mwansasu and Cranford Pratt, eds., Toward socialism in Tanzania (Toronto: University of Toronto Press, 1979), pp. 95-124.

335. BARKER, JONATHAN. "Uiamaa in cash-crop areas of Tanzania: some problems and reflections. Journal of African studies 1, no. 4 $(1974)=441-463$.

336. BAUM, ECKHARD. "Ujamaa ein Konzept der Agrar, und Siedlungspolitik in Tanzania." [Ujamaa, an agrarian concept, and settlement politics in Tanzania]. Zeitschrift fiir ausländische Landwirtschaft 10, no. 2 (1971): 114-124.

337. BAUM, ECKHARD. "Ujamaa villages: an approach to rural development in Tanzania." The South African journal of African affairs 3 , no. 2 (1973): 37-46.

338. BULEGI, S. A. "The role of villages as multi-purpose producer cooperatives in rural development." In Agricultural extension in ujamaa village development: papers and proceedings of a workshop, edited by Hermann Hansel, et al., pp. 19-27, Morogoro: University of Dar es Salaam, $19 \overline{75 .}$

339. GARDETTINI, O. Eléments d'une strategie d'écodéveloppement pour les villaqes Ujamaa de Tanzanie. [Elements of a strateqv of economic development for Tanzanian Uiamaa villages]. Thesis prepared for Ecole pratique des hautes Gtudes, Centre international de reserches sur l'environnement et le développenent, Paris, 1974. 91 p. Cited in CARDAN, Bibliographie francaise sur 1'afrique 7, no. 3 (1975): 102; 7, no. 4 (1975): 102; and 8, no. 3 (1976): 84, in which the author's name is spelled Cordettini.

340. CEDILLO, VALENTIN G. "Rural development through ujamaa, A Tanzania case report." (Occasional paper 73/11). Vienna: Vienna Institute for Development, 1973. $55 \mathrm{p}$.

341. CEDillo, VALENTin G, G. H. E. MWINAMA and R. P. A. S. MKOKOI. A study of the rural development programme, ujamaa villages and rural development staff of Tanga, Kilimanjaro and Arusha. Dar es Salaam: Government Printer, 1970. Cited by James Kocher and Beverly Fleisher, Bibliography on rural development in Tanzania (no.481).

342. CLIFFE, LIONEL. "The policy of ujamaa vijijini and the class struggle in Tanzania." Paper presented at the seminar on Changes in Tanzanian Rural Society and Their Relevance for Developrent Planning, Afrika-Studiecentrum, Leiden, Netherlands, December 1970. 25 p. Slightly revised and published in Rural Africana, no. 13 (1971): 5-27; and republished in Lionel Cliffe and John Saul, eds., Socialism in Tanzania, Vol. 2 (Dar es Salaam: EAPH, 1973), pp. 195-211. 
343. CLIFFE, LIONEL and JOHPJ S. SAUL, eds. Socialism in Tanzania: An Interdisciplinary Reader, Vol. II - Policies. Dar es Salaam: EAPH, 1973. $358 \mathrm{p}$.

344. CLIFFE, LIONEL; PETER LAWRENCE; WILLIAM LUTTERELL; SHEM MIGOTADHOLLA and JOHN SAUL, eds. Rural cooperation in Tanzania.

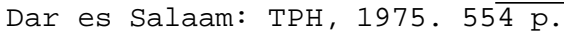

345. CONNELL, JOHN. "Ujamaa villages: institutional change in rural Tanzania." Journal of administration overseas 11, no. 4 (1972) : 273-283. Revised and published as The evolution of Tanzanian rural development (Brighton: University of Sussex, Institute of Development Studies, 1974), 21 p.; and in a slightly different form in the Journal of tropical geography 38 (1974): 7-18.

346. COULSON, ANDREW. "Agricultural policies in mainland Tanzania." Review of African political economy, no. 10 (1977): 74-100.

347. DARAJA, A. W. M. "The Tanzanian pattern of rural development: sone administrative problems." Student dissertation, Department of Political Science, University College, Dar es Salaam, 1970. Revised slightly and published in J. H. Procter, ed., in Building ujamaa villages in Tanzania (Dar es Salaam: TPH, 197I), pp. 48-54.

348. DESAI, P. M. "Ujamaa villages: a Tanzanian experiment in rural development" Africa quarterly 16, no. 2 (1976): 36-55.

349. DE VRIES, JAMES and H. HANSEL. "Ujamaa villages as a strategy for rural development in Tanzania." In Agricultural extension in ujamaa village development: papers and proceedings of a workshop, edited by Hermann Hansel, et al., pp. 28-63. Moroyoro: University of Dar es Salaam, $19 \overline{75 .}$

350. ELLIIAN, ANTONY. "Agricultural improvements through cooperative farming in Tanzania: a brief outline." (ERB paper 69.32). University College, Dar es Salaam, 1969. 10 p. Published as "The introduction of agricultural innovations through cooperative farming: a Brief outline of Tanzania's Policies," East African journal of rural development 3, no. 1 (1970): $1-15$.

351. ELLMAN, ANTONY. "Development of ujamaa farming." Paper presented at the seminar on Changes in Tanzanian Rural Society and Their Relevance for Development Planning, Afrika-Studiecentrum, Leiden, Netherlands, December 1970. 30 p. Published in Kroniek van Afrika, no. 2 (1971): 113-130.

352. ELLMAN, ANTONY. "Development of ujamaa policy in Tanzania." In Rural cooperatives in Tanzania, edited by Lionel Cliffe, et al., pp. 312-345. Dar es Salaam: TPH, 1975.

353. ELLMAN, ANTONY. "Group farming experiences in Tanzania." In Cooperative and conmune, edited by Peter Dorner, pp. 234-276. Madison: University of Wisconsin Press, 1977.

354. ELLMAN, ANTONY. "Progress, problems and prospects in ujamaa development in Tanzania." Paper presented at the East African Economics Society conference, Dar es Salaam, 31 March 4 April 1970. 4i p. Published as ERB Paper 70. 18, University College, Dar es Salaam, 1970, 35 p. 
355. Field Research in Tanga Ujamaa Villages. A collection of student papers prepared for the Department of Sociology, University of Dar es Salaam in 1973 and 1974, 1975. Mimeographed. $456 \mathrm{p}$. The Library of Congress entry indicates the papers were prepared between 1974 and 1977 and that the volume contains $538 \mathrm{p}$. Yet, the Library of Congress copy contains only $456 \mathrm{p}$. and is limited to papers prepared between 1973 and 1974. There is a three page introduction by B.C. Nindi and G. Philippson.

356. FORTMANN, LOUISE. Peasants, officials and participation in rural Tanzania: experience with villagization and decentralization. (Rural local organization series no. 1) . Rural Development Committee, Center for International Studies, Cornell University, Ithaca, New York, 1980. 148 p.

357. GHAI, DHARAM and REGINOLD HERBOLD GREEN. "Ujamaa and villagisation in Tanzania." In Agrarian systems and rural development, edited by Dharam Ghai, Azizur Rahman Khan, Eddy Lee and Samir Radwan, pp. 232-256. New York: Holmes and Meier, 1979 .

358. GHAI, DHARAM, EDDY LEE, JUSTIN MAEDA and SAMIR RADWAN, eds. Overcoming rural underdevelopment: proceedings of a workshop on alternative agrarian systems and rural development, Arusha, Tanzania 4-14 April 1979. Geneva: International Labour Office, 1979. 98 p.

359. GODDING, JEAN-PIERRE. "La politique rurale et les villages ujamaa." [Rural politics and Ujamaa villages]. In Conference Olivaint de Belgique, Ia Tanzanie: une leader, une experience, un espoir: session d'etude 4 aout-2 septembre 1974: rapports des participants, pp. 282-305. Bruxelles: Conference Olivaint de Belgique, 1975?

360. HESS, OLEEN. "Tanzania: ujamaa and development." (International Agriculture Mimeograph no. 52). Department of Agricultural Economics, Cornell University, Ithaca, New York, 1976. 86 p.

361. HEWLETT, ROBERT and JOHN MARKIE. "Cooperative farming as an instrument of rural development: examples from China, Vietnam, Tanzania and India." Land reform, no. 2 (1976): 41-54. Relevant pages are 46-48.

362. HILL. FRANCES. "Uiamaa: African socialist productionism in Tanzania." In Socialism in the Third World, edited by Helen Desfosses and Jacques Levesque, pp. 216-252. New York: Praeger, 1975.

363. HUIZER, GERRIT. "The ujamaa village programme in Tanzapia: new forms of rural development." (Occasional papers no. 11). The Hague: Institute of Social Studies, 1971. 30 p. Published in Studies in comparative international development 8 , no. 2 (1973) : 183-207.

364. HYDEN, GÖRAN. Beyond ujamaa: underdevelopment and an uncaptured peasantry. Berkeley: University of California Press, 1980. $270 \mathrm{p}$.

365. HYDEN, GÖRAN. "Ujamaa, villagisation and rural development." Overseas development institute review, no. 1 (1975): 53-72. 
366. HYDEN, GÖRAN. "Villagization, population growth, and agricultural development in Tanzania." Paper presented at the East African Agricultural Economic Society conference on population growth and agricultural development, Kampala, Uganda, May 1975. 9 p.

367. INUKAI, I. "African socialism and agricultural development strategy: a comparative study of Kenya and Tanzania." The developing economies 12, no. 1 (1974): 3-22.

368. JOBS AND SKILLS PROGRAMME FOR AFRICA. INTERNATIONAL LABOUR OFFI$\mathrm{CE}$. "Changes in the rnstitutional framework: villagisation and ujamaa." In Towards self-reliance: development, employment and equity issues in Tanzania, pp. 41-55. Addis Ababa: International Labour Office, 1978.

369. JUMA, RICHARD S. "Ujamaa development in Tanzania." In Ujamaa and self-reliance: building socialism in Tanzania, editedby Marilee Karl, pp. 36-37. Rome: IDOC, 1976.

370. KAYOMBO, E. O.; H. H. LUSWAGA, S. MESAKI and 0. M. M. NGALYA. A collection of essays on ujamaa villages. Four student dissērtations, Department of Political Science, University of Dar es Salaam, 1971. 109 p.

371. KEREGERO, K. J. B. and A. Z. MATTEE. "Villagization and rural development: a comment." In Agricultural extension in ujamaa village development: papers and proceedings of a workshop, edited by Hermann Hansel, et al., pp. 22-21. Morogoro: University of Dar es Salaam, 1975.

372. KIM, KWAIN S., ROBEKT B. MABELE and MICAHEL J. SCHULTHEIS, eds. Papers on the political economy of Tanzania. Nairobi: Heinemann Educational Books, 1979. 294 p.

373. KOMANYA, L. B. "Creating viable ujamaa villages." In Agricultural extension in ujamaa village development: papers and proceedings of a workshop, edited by Hermann Hansel, et al., pp. 64-69. Morogoro: University of Dar es Salaam, 1975.

374. MAPOLU, HENRY and G. PHILIPPSON. "Agricultural cooperation and the development of productive forces: some lessons from Tanzania." The African review 6, no. 2 (1976): 143-163.

375. MARKIE, JOHN. "Ujamaa villages in Tanzania: a possible solution to the problems of the rural poor." Land reform, no. 1 (1976) : $54-76$.

376. MASCARENHAS, ADOLPḦO. "After villagization - what?" In Towards socialism in Tanzania edited by Bismarck Mwansasu and Cranford Pratt, pp. 145-165. Toronto: University of Toronto Press, 1979 .

377. MASCARENHAS, ADOLPHO. "SOCial and institutional framework for implementing rural development approaches and constraints: the case of Tanzania." In Report on the FAO/SIDA expert consultation on policies and institutions for integrated rural development, Nairobi, Kenya, September 1976, Vol. 2, pp. 16-22. Rome: FAO, 1977.

378. MCHENRY, DEAN E., JR. "Concentrations and ujamaa villages: a note on resettlemect efforts in Kigoma region." Taamuli 5, no. 1 $(1975): 54-59$. 
379. MCHENRY, DEAN E., JR. "The ujamaa village in Tanzania: a comparison with Chinese, Soviet and Mexican experiences in collectivization." Comparative studies in society and history 18, no. $3(1976)=347-370$.

380. MEYEN, W. L. "Ujamaa village development in Mbeya region." (ERB paper). University of Dar es Salaam, n.d. Cited by C. Boalt, "Village housing in Tanzania" (no. 272).

381. MEYNS, PETER. Nationale Unabhangiegkeit und landliche Entwicklung in der 3. Welt: Das Beispiel Tanzania. [National Independence and Rural Develoment in the Third World: the Tanzanian Example]. Berlin: Oberbaumverlag, 1977? 298 p.

382. MLAMBiti, M. E. "Rural development: The Tanzanian type." Paper presented at the East African universities social science conference, Dar es Salaam, December 1973. Published in Tanzania notes and records, no. 79/80 (1976): 1-12.

383. MODERNE, FRANK. "Etude comparative de deux institutions socialistes du développement rural dans l'océan indien: le fokonolona Malgache et le village ujamaa Tanzanien." [comparative study of two socialist institutions for rural development in the Indian Ocean: the Fokonolona of Madagascar and the ujamaa villages of Tanzania]. Annuaire des pays de l'océan Indien 1 $(1974)$ : 235-259.

384. MODERNE, FRANK. "La cooperation agricole en Manzanie." Terre lialgache $8(1970): 61-82$.

385. MODERNE, FRANK. "Noveaux développements de l'experience des viliaces ujamaa en Tanzanie." "New development in the experience of Ujamaa villages in Tanzania 7 . Revue Francaise d'etudes politiques Africanines, no. 61 (1971): 62-86.

386. MODERNE, FRANK. "Villages cornmunautaires et socialisme Tanzanien" [Communal villages and Tanzanian socialism;. Développement et civilisations, no. 39-40 (1970) : $147-166$.

387. MODERNE, FRANK. "Les villages ujamaa et l'edification du socialisme en Tanzanie." [Ujamaa villages and the building of socialism in Tanzania]. Revue economique de Madagascar, no. 5 $(1970): 363-381$.

388. MUSHI, SAMUEL S. "Revolution by evolution: the Tanzanian road to socialism." Ph.D. dissertation, Department of Political Science, Yale University, 1974. 484 p.

389. OMARI, C. K. "Operation Kigoma, Kibondo district: a preliminary appraisal." (Rural Development Research Committee report no. 2). Department of Sociology, University of Dar es Salaam, 1973. $38 \mathrm{p}$.

390. OMARI, C. K. Strategy for rural development, Tanzania experience. Kampala: EALB, 1976. 168 p.

391. OMARI, C. K. "Tanzania's emerging rural development policy." Africa today 21, no.3 (1974): 9-14.

392. PHIIIP, CHRISTIAN. "Le socialisme Tanzanien et les villages ujamaa, base de son Qdification." [Tanzanian socialism and ujamaa villages, the foundation of its construction]. Memoire, Diplome d'etudes Superieur, Science Politique, Faculte des Sciences Economiques? Paris, 1970. 
393. SCHULTZ, PETER. "Tanzanie: la parole est au village." [Tanzania: the talk is of the village]. Croissance des jeunes nations, no. 143 (1974): 31-33.

394. SCHÜTTE, HEINZ. "Ujamaa Villages und Nyereres Afrikanischer Sozialismus." Internationales Afrika Forum 5, no.4 (1969): 282-287.

395. SVENDSEN, KNUD ERIK. "General problems of the rural development policy of Tanzania." Paper prepared for a seminar on foreign aid and rural development, Organization for Economic Cooperation and Development, Dar es Salaam, January 1970. 14 p.

396. TANU, BODI YA UHARIRI. "Watanzania vijijini." [Tanzanians in the villages]. In Kujenga ujamaa Tanzania: miaka kumi ya kwanza, pp. 163-177. [Dodoma]; TANU, 1977.

397. TANZANIA, 'IDARA YA MAENDELEO YA UJAMAA NA USHIRIKA. OFISI YA WAZIRI MKUU NA MAKAMU WA PILI WA RAIS. Maendeleo ya ujamaa na ushirika Tanzania, iThe development of socialism and cooperatives in Tanzania!. Dodoma: Ofisi ya Waziri Mkuu, 1976. 43 p.

398. TANZANIA. KIKUNDI CHA TAKWIMU. SEHEMU YA MIPANGO NA UTAFITI. OFISI YA WAZIRI MKUU NA MAKAMU WA PILI WA RAIS. Maendeleo ya vijiji vy ujamaa. [Progress of ujamaa villages]. Dar es sal laam: Kikundi cha Takwimu, 1974. 60 p.

399. TANZANIA. MINISTRY OF COMMUNITY DEVELOPMENT. Ujamaa villages: a collection of original manuscripts, 1969-1970. Dar es Salaam: 1970. 108 P. Typewritten and mimeographed manuscripts collected by Eugene de Benko, Michigan State university,-in March 1971 from the Ujamaa Village Project in the Ministry of Community Development, Dar es Salaam.

400. TANZANIA. OFISI YA WASIRI MKUU NA MAKAMU WA PILI WA RAIS. IDARA YA UJAMAA NA USHIRIKA. SEHEMU YA MAENDELEO YA SIASA NA UTAFITI. Maendeleo ya vijiji. Dodoma: Sehemu ya Maendeleo ya Siasa na Utafiti, 1975. I6 p. Cited in Tanzania National Bibliography, 1974-75.

401. TANZANIA. PRIME MINISTER AND SECOND VICE PRESIDENT'S OFFICE. Maendeleo ya vijiji vya ujamaa. Dar es Salaam: Prime Minister's Office, 1973. 15 p. Cited in Printed in Tanzania, 1973.

402. TSCHUDI, A. B. "Ujamaa villages and rural development." Norsk geografisk tidsskrift 26 , no. 1/2 (1972): 27-36.

403. "Ujamaa, the rural revolution." Jenga, no.8 (1971): 1-7. Reprinted as "Rural revolution in Tanzania." African progress 1 , no. $4(1971)=32-35$.

404. UNIVERSITY OF EAST ANGLIA. OVERSEAS DEVELOPMENT GROUP. "Agricultural Organisation and village settlement." In Irinqa region, Tanzania: integrated rural development proposals for the third five-year plan, 1976-81, vol. I, pp. 5.1-5.22. Rome: FAO, 1976 .

405. URFER, SYLVAIN. Une Afrique socialiste, la Tanzanie. [Socialist Africa, Tanzania]. Paris: Les Editions Ouvrieres, 1976. 239 p. The relevant section is pp. 70-81.

406. WEEKS, SHELDON. "Building ujamaa: Tanzania's rural socialist villages." Paper prepared for a public lecture given at the University of Papua New Guinea, April 1975. 28 p. 
407. WOLSTENHOLME, CHRIS. "Ujamaa." New internationalist, May, 1973, pp. 16-18.

2. Assessment of success

408. ANDREOU, P. and SHARMA, K. L. "Approche économique du mouvement Ujamaa et du développement rural cooperatif en Tanzanie." [Economic approach of the Ujamaa movement and rural cooperative development in Tanzania]. Revue des etudes cooperatives, no. 187 (1977) : 115-123.

409. ANGWAZI, JOSEPH and BENNO NDULU. "Evaluation of Operation Rufiji, 1968." (BRALUP service paper 73/9). University of Dar es Salaam, 1973.

410. ANGWAZI, JOSEPH and BENNO NDULU. "An evaluation of ujamaa villages in the Rufiji area, 1968-1972." Paper presented at the East African universities social science conference, Dar es Salaam, December 1973. 22 p.

411. AWITI, ADHU. "The development of ujamaa villages and the peasant question in Iringa district: a study outline." (ERB

(procedural) paper 71.1). University of Dar es Salaam, 1971. 39 p. Reissued as ERB paper 73.4, University of Dar es Salaam, 1973, 48 p.

412. AWITI, ADHU. "Economic differentiation in Isrnani, Iringa region: a critical assessment of peasants' response to the ujamaa vijijini programme." Paper presented at an ERB Seminar, University of Dar es Salaam, October 1972. $47 \mathrm{p}$. Reprinted as "Class struggle in rural society of Tanzania", Maji Maji, no. 7 (1972); under the original title in The African review 3, no. 2 (1973): 209-240; with three new introductory pages as "Analysis of a rural village in Tanzania." African red family 1, no. 1 (1973): 26-61; split into two parts as "Ismani and the rise of capitalism" and "The development of ujamaa in Ismani," in Lionel Cliffe, et. al., eds., Rural Cooperation in Tanzania (Dar es Salaam: TPH, 1975), $\overline{\mathrm{pp} .}$ 5178 and 418-425, respectively; and as "Lutte des classes dans la societe rurale de la Tanzanie: une etude de cas de Ismani-Iringa," in Samir Amin, ed., L'agriculture Africaine et le capitalisme (Paris: Editions Anthropos, 1975), pp. 257318 .

413. BLUE, RICHARD N. and JAMES H. WEAVER. A critical assessment of the Tanzanian model of development. (Occasional paper no.1). Washington, D. C.: Agency for International Development, Development Studies Program, June 1977, 61 p. Reprinted by the Agricultural Development Council, no. 30, July 1977, 19 p.

414. BOGGIO, BERNARD and PIERRE-YVES DOUET. "Tanzanie, comment fonctionnent les villages communautaires ujamaa." [Tanzania, how the Ujamaa villages function!. Croissance des jeunes nations, no. 164 (1975) : 11-14.

415. BRYCESON, DEREK. "Village settlements scheme now well on way to success." African Development, December 1971, pp. T17-T20.

416. CHAMBERS, ROBERT. "Book review: building ujarnaa village in Tanzania." Taarnuli 2, no. 2 (1972): 62-66. 
417. CLIFFE, LIONEL; WILLIAM LUTTERELL and J. E. MOORE. "SOcialist transformation in rural Tanzania: a strategy for the western Usambaras." (ERB paper 69.24). University of Dar es Salaam, 1969. 47 p. Presented at the East African universities social science conference, Nairobi, Kenya, December 1969 and reprinted in slightly revised form as "Socialist development in Tanzania agriculture: its application to the western Usambaras" in Lionel Cliffe, et al., eds., Rural cooperation in Tanzania (Dar es Salaam: TPH, 1975), pp. 506-538.

418. "Cooperative villages in near revolt..." Free Zanzibar voice, October 1974, pp. 6-9.

419. COULSON, ANDREW, ed. African socialism in practice: the Tanzanian experience. Nottingham, England: Spokesmen Books, 1979.

420. ELLIS, RAY. "Ujamaa: a personal assessment." Africa report 19, no. $6(1974): 42-45$.

421. ERGAS, ZECKI. "La politique des villages ujamaa en Tanzanie: la fin d'un mythe." [The politics of ujamaa villages in Tanzania: tine end of a myth]. Revue Tiers-monde 20, no. 77 (1979): $169-186$.

422. FIRSt, RUTh. "How ujamaa works." Africa, no. 21 (1973): 40-43.

423. GIGER, HEINI; URS LENDENMANN; HANNY LUTTOLF and HANSRUEDI SCHWEIZER. Tansania, ein Kritischer Reisebericht. [Tanzania, a critical tour report]. Zïrich: Schweizerische Arbeitsgruppen für Entwicklungspolitik, 1976. 81 p. Particularly relevant are pp. 24-29.

424. GREEN, REGINALD. "Ujamaa: success or failure?" African development 9, no. 1 (1975): 12-13.

425. GRUHN, ISEBIL V. "Tanzania's noble experiment imperiled." Worldview 19, no. $10(1976): 23-25$.

426. HONNOLD, EDWARD. "Tanzania's struggle for ujamaa: towards a rural utopia?" Foreign service journal 53, no. 2 (1976) : 7-11, 25 .

427. JOINET, BERNARD. "I'ujamaa et le développement agricole en Tanzanie socialiste." Revue des studes cooperatives, no. 192 $(1978)$ : $67-94$.

428. JUMA, RICHARD. "Ujamaa in practice." African development, December 1970, p. T21.

429. KIVA, A. V. "Tropicheskaia Afrika: nekotorye problemy revoliutionno-demokraticheskikh preobrazovanii $v$ derevne ('Udzhamaa' v Tanzanii)." Tropical Africa: Some Problems of the Revolutionary-democratic Transformations in the Village (Ujamaa in Tanzania)]. Narody Azii i Afriki 20, no. 5 (1974) : 15-25.

430. KJEKSHUS, HELGE. "The Tanzanian villaqization policy: implementation lessons and ecological dimensions." Canadian journal of african studies 11, no. 2 (1977): 269-282.

431. RÜRSCHNER, F. "Das Konzept der Ujamaa-Dorfer: Eine Kritische Bestandsaufnahme." Afrika Spectrum 10, no. 3 (1975) = 245-262. 
432. IEWIN, ROGER and GRIFFITHS CUNNINGHAM. "The prospects for ujamaa villages." In Self-Reliant Tanzania, edited by Knud Eric Svendsen and Merete Teisen, pp. 272-280. Dar es Salaam: TPH, 1969.

433. LOFCHIE, MICHAEL. "Agrarian crisis and economic liberalisation in Tanzania." The journal of modern African studies 16, no.3 $(1978)=451-47 \overline{5}$.

434. LOFCHIE, MICHAEL. "Agrarian socialism in the Third World: the Tanzanian case." Comparative politics 8, no. 3 (1976): 479499 .

435. MAEDA, JUSTIN H. J. "Managing the ujamaa village development in Tanzania: an assessment of the implementation of the rural ujamaa policy." Paper presented at the sixteenth Inter-African Public Administration and Management Seminar, Banjul, the Gambia, 28th November-3rd December, 1977. Cited in Susanne Mueller, "Landing the middle peasantry'' (no. 442).

436. MAEDA, J. H. J. and IBRAHIM M. KADUMA. "Self-reliance and ujamaa: Tanzania's development strategy." In What now? The Daq Hammarskjold report, pp. 54-59. Uppsala: Dag Hammarskjold Foundation, 1975. Summary of a longer paper they prepared for the 1975 Dag Hammarskjold Project.

437. MAPOLU, HENRY. "Mjadala na wakulima wa kijiji cha Isesa, wilaya ya Mwanza." LDebate with peasants of Isesa Ujamaa village, Mwanza district]. Maji Maji, no. 10 (1973) : 22-29.

438. MATANGO, R. R. "'Operation Mara:' the paradox of democracy." Maji Maji, no. 20 (1975) : 17-29.

439. MBILINYI, MARJORIE J. "The transition to capitalism in rural Tanzania." (ERB paper 74.7). University of Dar es Salaam, 1974. 49 p. Relevant section is pp. 34-40.

440. MCKINSEY \& CO. Strengthening the ujamaa village programme: a progress review. Dar es Salaam: Government of Tanzania, 1974.

441. MIGOT-ADHOLLA, S. E. "Rural development policy and equality." In Politics and public policy in Kenya and Tanzania edited by Joel D. Barkan and John J. Okumu, PP. 154-178. New York: Praeger, 1979.

442. MUELLER, SUSANNE D. "Landing the middle peasantry: Narodism in Tanzania." (Working paper no. 20). Brookline, Mass.: African Studies Center, Boston University, 1979. 32 p. Revised and to be published in Ralph Miliband and John Saville, eds., The Socialist Register (London: Merlin Press, 1980).

443. MUNGAI, JOSEPH H. "Ujamaa and rural development." Africa, no. 48 $(1975): 23-26$.

444. MWANSASU, BISMARCK U. and CRANFORD PRATT, eds. Toward Socialism in Tanzania. Toronto: University of Toronto Press, $243 \mathrm{p}$.

445. NDAWULA-KAJUMBA, S. "Is the selectiveness of wajamaa and the unselectability of farm work a future problem for Tanzania's state farm sector." Paper presented at an ERB seminar, University of Dar es Salaam, 6 August 1974. 20 p. 
446. NGASONGWA, J. A. "An assessment of socialist rural transformation in Tanzania during the first decade of the Arusha Declaration." Mbioni 8, no. 7 (1977): 16-43.

447. NGOTYANA, R. "The strategy of rural develowment: Tanzania's second five-year plan." The African communist, no. 39 (1969): 24-38. Reprinted as "The strategy of rural development" in Lionel Cliffe and John Saul, eds., Socialism in Tanzania, Vol. 2 (Dar es Salaam: EAPH, 1973), pp. 122-128.

448. NGUNANGWA, N. "Socialism and Tanzania rural strategy." Maji Maji, no. $27(1976)=42-56$.

449. NURSEY-BRAY, P. F. "Tanzania: the development debate." African Affairs 79, no. 314 (1980): 55-78.

450. NYERERE, JULIUS $K$. The Arusha Declaration, ten years after. Dar es Salaam: Government Printer, 1977. 51 p.

451. PUTTERMAN, LOUIS. "Is a democratic collective agriculture possible? Theorectical considerations and evidence from Tanzania." (Working paper no. 80-18). Department of Economics, Brown University, Providence, Rhode Island, 1980. 33 p.

452. PUTTERMAN, LOUIS. "The producers' organizational choice; theory and the case of the Tanzanian villages." Ph.D. dissertation, Department of Economics, Yale University, 1980. 729 p. The dissertation is bound in two volumes.

453. PUTTERMAN, LOUIS. "Voluntary collectivization: a model of producers' institutional choice." Journal of Comparative Economics 4 (1980): 125-157.

454. RAIKES, PHIIIP. "Agrarian crisis and economic liberalisation in Tanzania: a comment." Journal of modern African studies 17, no. 2 (1979) : 309-316.

455. RAIKES, PHILIP L. "Economic evaluation criteria for ujamaa villages." (ERB paper 73.3). University of Dar es Salaam, 1973. $36 \mathrm{p}$.

456. RAIKES, PHILIP. "Settlement, villagization and ujamaa in Tanzania." (Centre for Development Research project paper

D. 77.2). Copenhagen: Centre for Development Research, 1977. 29 p. Draft of chapter 8 of a book in preparation to be titled State and agriculture in Tanzania.

457. RAIKES, PHILIP L. "Ujamaa vijijini and rural socialist development." Paper presented at the East African universities social science conference, Dar es Salaam, December, 1973. 32 p. Republished by the Institute for Development Research, Copenhagen as research paper A 74.4, 1974; and as "Ujamaa and rural socialism," Review of African political economy, no. 3 (1975) : 33-52, with a postscript up-dating it to early 1975.

458. RAKE, ALAN. "Too soon to judge ujamaa yet." African development 9, no. 12 (1975) : 81 and 83.

459. RUPIA, J. A. J. "Umuhimu wa vijiji vya ujamaa katika maendeleo ya Tanzania." [The importance of ujamaa villages in the development of Tánzania]. Ujamaa, no. 38 (1974): 1-68. 
460. SANDBERG, AUDUN. "Ujamaa and control of environment." Paper presented at the East African universities social science conference, Dar es Salaam, December 1973. 23 p.

461. SEIDLITZ, PETER. "The failure of Tanzania's collective agriculture." Swiss review of world affairs 24, no. 10 (1975): 18-19.

462. SHIVJI, ISSA G. Class struggles in Tanzania. Dar es Salaam: TPH, 1975. 182 p. Part 4, pp. 101-120, deals with Ujamaa villages.

463. SVENDSEN, K. E. "General problems of rural development policy in Tanzania." In Socialism in Tanzania, Vol. 2, edited by Lionel Cliffe and John Saul, pp. 180-185. Dar es Salaam: EAPH. 1973. Prepared in January 1970.

464. SWEET, C. LOUISE. "Obstacles to the creation of collective villages in Tanzania: a discussion of ideology and administration." Paper presented at the annual meeting of the African Studies Association, Houston, Texas, November 1977. 24 p.

455. SWEET, C. LOUISE. "Rural equality versus rural development among the Luguru peoples of eastern-central Tanzania." Ph.D. dissertation, University of California, Berkeley, 1976. 575 p.

466. "Tanzania: ujamaa revisited." Africa confidential 19, no. 22 $(1978): 5-7$.

467. TEMU, PETER E. "The ujamaa experiment." Ceres 6, no. 4 (1973): 71-75. Reprinted in Kwan Kim, Robert B. Mabele and Michael J. Schultheis, eds., Papers on the political economy of Tanzania (Nairobi: Heinemann, 1979), pp. 197-201.

468. ZEGGE, BARNABAS K., et al., "A performance analysis of UpperKitete Ujama Village." Paper prepared for the Office of the Prime Minister and Second Vice President, Rural Development Division, Dar es Salaam. 1973. Cited in Rolf D. Baldus, Zur Operational en Effiziens der Ujamaa Kooperative Tanzanias (no. 333).

469. ZEGGE, BARNABAS K. "Ujamaa Villages Program: Past and Present." Paper presented at the Workshop on Development from Below, Addis Ababa, October, 1973. Cited in James Kocher and Beverly Fleisher Bibliography on rural development in Tanzania (no. 48I).

E. General Sources: Journals, Newsnaners \& Bibliographies

There is one journal which has been devoted almost entirely to material on ujamaa villages and there are several newspapers which have contained relevant articles almost daily. Several bibliographies, mentioned in the introduction, are listed in this section.

\section{Journals}

470. Ujamaa ieo (Dar es Salaam). Published irregularly since May 1974. Issued by the Prime Minister's Office. 
2. Newspapers

471. Daily News (Dar es Salaam). Published six days each week since 26 April 1972. Owned by the government. Formed by the merger of The Standard and the Nationalist.

472. Mzalendo (Dar es Salaam). The sunday Swahili newspaper published by the party since 30 April 1972 .

473. Nationalist (Dar es Salaam). Party newspaper published between 17 April 1964 and 25 April 1972.

474. The Standard (Dar es Salaam). Privately owned from 1929 to February 1970, when the covernment nationalized the paper. Originally appeared as the Tanganyika Standard. Since January 1965 it appeared as The Standard and the Tanzania Standard. Published six times a week until 25 April 1972 when it merged with the Nationalist to form the Daily News.

475. Sunday News (Dar es Salaam). The sunday issue of the Standard/ Daily News. Government owned since February 1970.

476. Uhuru (Dar es Salaam). Swahili newspaper published six times a week since 1961. Owned by the party.

477. Ushirika (Dar es Salaam). Monthly newspaper published by the Cooperative Union of Tanganyika since 1964.

3. Bibliographies

478. DE VRIES, JAMES. Selected bibliography on agricultural extension in Tanzania. (Technical paper no. 3). Morogoro: Department of Rural Economy, Faculty of Agriculture, Forestry and Veterinary Science, University of Dar es Salaam, 1978. 44 p.

479. HUNDSDÖRFER, VOLHARD and WOLFGANG KƯPER. Bibliographie zur Sozialwissenschaftlichen Erforschung Tanzanias. ; Bibliography for social science research in Tanzania]. (Arnold-Bergstraesser-Institut, Materialien zu Entwicklung und Politik, 6.). Munich: Weltforum Verlag, 1974. 231 p.

480. KAI-SAMBA, IBRAHIM B.; SALUM S. MBWANA and VALLERY G. MAHOMBA. Development for self-reliance: a bibliography of contributions from the Faculty of Agriculture, Forestry and Veterinary Science, University of Dar es Salaam, 1967-1977. (Iibrarv occasional paper). Morogoro: The Library; Faculty of Agriculture, Forestry and Veterinary Science, University of Dar es Salaam, December 1977. 154 p. Citations in this bibliography are to materials found in the Library of the faculty of Agriculture, Forestry and Veterinary Science, University of Dar es Salaam, Morogoro.

81. KOCHER, JAMES E. and BEVERLY FLEISCHER. A bibliography on rural development in Tanzania. (MSU rural development paper no. 3) . East Lansing: Department of Agricultural Economics, Michigan State University, 1979. $77 \mathrm{p}$. The co-author's name is misspelled on the cover: it should be Fleisher. The bibliography is a revised version of one with the same title by James Kocher published as development discussion paper no. 30, Harvard Institute for International Development, Cambridge, Massachusetts, June, 1977, 30 p. 
482. MÖLLER, TIES, compiler. Tansania: Ujamaa und Entwicklungsplanung - ausgewahlte Neuere Literatur. [Tanzania: ujamaa and development - selected new literature]. (Dokumentationsdienst Afrika, 4). Hamburg: Deutsches Institut fur Afrika-Forschung, 1972. $65 \mathrm{p}$.

483. MÖLLER, TIES and ANNE JANSEN, Compilers and editors. Wirtschafts-, Agrar- und Sozialpolitik in Ostafrika (Kenia, Tansania) ausgewahlte neuere Literatur. LEconomic, agricultural and social policy in East Africa (Kenya, Tanzania) - selected recent literature]. (Dokumentationsdienst Afrika, Reihe A, 8). Hamburg: Deutsches Institut für Afrika-Forschung, 1974. 189p.

484. SUMAR, M. and E. MCGEE, compilers. National policies of Tanzania: a bibliography. Dar es Salaam: Tanganyika Library Service, 1972. $66 \mathrm{p}$.

485. TANZANIA LIBRARY SERVICE. Subject index to "The Nationalist" 1964 - 1972. Dar es Salaam: Tanzania Library Service, 1977. 250 p. Relevant citations are classified under Tanzania, Ujamaa and Ujamaa villages, pp. 216-219.

486. "Tanzania bibliography." Tanzania notes and records, published each year usually in July. Compiled from 1968 to 1974 by B.W. Langlands. 


\section{INDEXES}

\section{A. Subject Index}

In addition to a variety of topical entries, the subject index includes a listing of the villages/ujamaa villages which have been the subject of study. Each village is listed in capital letters and is followed by a citation of the district in which the village is located. District headings include the studies of villaqes that fall in the given district; regional headings do not include the studies of villages which fall in the given region. Other geographical headings are included if they were the unit within which ujamaa villages were studies.

Agricultural extension, 185, 187, 189-191, 195, 202, 203, 213, 214, 219,225 ; evaluation of , 188, 193, 194, 199, 207; planning and, $205,215,217,219$; training of agents for, 196, 209-211, 220; see also Government staff, agriculture

Agricultural marketing, 244; see also Cooperatives

Agricultural production, 6, 26, 175, 241, 257, 263, 265, 268, 273, 346,350 ; effect of villaqes on, 433, 434, 454, 457; cashew nut, 135 ; coffee 242; dairy, 46, 248; egg, 247; fish, 14, 254; livestock, 232, 233; maize, 250; seaweed, 253; sisal, 129, 246; tea, 46; tobacco, $115,154,241,242,249,255,411$; vegetable, 231; wheat, 245, 259; see also Communal activities, agriculture

Arumeru district, 198, 320, 452

Arusha district, 126

Arusha region, 356, 358

Bagamoyo district, $19,98,178,229$

BENDERA (Pare), 198

Best village award: reasons for prize, 197; winning villages in 1972, 198; winning villages in 1975, 229

Biharamulo district, 84, 35, 229

BISUMWA (Musoma), 272

Block farms, 101,410

Book/article reviews, 416, 434, 242, 454

BUJAMBA (Njombe), 426 
BUKABUYE (Bukoba), 108

BUKANGARA (Karagwe), 160

Bukoba district, 42, 46, 69, 108, 198, 326, 329, 330, 381

BUNJU (Mzimzima), 331

BUTIAMA (Musoma), 118, 162, 167, 276

Bwakira Chini settlement (Morogoro), 1

Central Hai division (Kilimanjaro), 110

CHAKACHANI (Tanga), 150

CHAMWINO (Dodoma Rural), 157

CHANGALIKWA (Korogwe), 11, 132, 164, 347

CHEKERENI (MOShi), 59, 358

CHIKUNDI (Iindi), 198 ,

CHOLOLO (Dodoma), 276

Chunya district, 198

Coast region, 66, 198, 331, 409

Communal activities:

Aqricultural: $64,258,320,323,324,334,434$; in Bukoba District, 326; Handeni District, 265, 315; Lushoto District, 231; Musoma District, 118 ; Njombe District, 175; Rufiji District, 152; Sumbawanga District, 245; Ufipa District, 268; in Iringa Region, 262, 404; Mwanza Region, 263, 264; Tanga Region, 44, 46, 123; West Lake Region, 179;

Non-agricultural: 123, 320, 307; in Musoma District, 118;

Traditional: 56, 332; see also items in Section II B2

Comparison with other undertakings: China, USSR and Mexico, 379;

China, Vietnam and India, 361; Fokonolona i n Madagascar, 383;

Kenya, 367

Constitutions; village, 323

Cooperatives, $88,89,96,97,206,216,275,287,408$; disbanding of, 35; fishing, 14; leaders of, 223; marketing, 22; multi-purpose,

$36,109,282,338 ;$ traditional forms, 3, 100

Credit, 223, 234, 237-242, 252, 260, 261, 386; see also National Development Corporation and Rural Savings and Credit Scheme

Dodoma region, 64, 128, 321, 323, 324, 358, 362, 381

Dodoma Rural district, 11, 128, 157, 200, 229, 272, 276, 362 
Economy, 175, 275; see also Agricultural production, Industry and Productive forces

Education, 280, 284, 304, 305, 311, 314; adult, 219, 290, 291; 1ibraries, 271; political education materials, 273, 275, 277, 285 , 293-295, 301-303; see also Agricultural extension, training of agents, Rural Training Center, and Village Management Training Programme

ENDAKISO (Hanang), 320,358

Evaluation of, 337,$360 ;$ see also items in Section II D2

Fishing, see Agricultural production, fish

Foreign assistance, 123,312

Formation of villages/ujamaa villages, 333, 335, 340, 342, 351, 357, $360,376,457$; government advice, 273, 275; i n Dodoma district, 200; i n Iringa district, 90, 94, 412; i n Mwanza region, 151; in Tanga region, 123; i n West Lake region, 45; use of force in, 29, $39,80,221,224$; villagization, 45, 338, 371, 430; see also Operation Vijiji, Problems and Section II B 1

GAIRO (Kilosa) , 260

GALLU (Ukerewe), 322

GAVAO-SAWENI ( $\mathrm{P}$ a r e ), 165

Geita district, 49, $106,229,263$

GEZAULOLE (Temeke), 229

Government staff，46，52，95, 110, 121, 123，192，333，356，457，462; asriculture. 186, 201,208, 350; community development, 200 , 230 ; - technical, 312; see also Political party leaders; Rural cadre and cooperatives

GUA (Chunya), 198

Hanang district, 229, 320, 452

Handeni district, 11,92, $119,121,122,129,132,138,149,150$, $172,192,246,265,300,315$

He alth, 276

Hongi settlement (Mbinga), 100

Housing , 272, 306 
IBANDA (Geita), 263

Ichungu division (North Mara), 438

Ideology, 27, 30, 123, 257, 275, 354, 431, 432; Nyerere's formulation, $31-39,450 ;$ as policy, 26, 29, 64

IDIBO (Kilosa), 260

IGONGOLA (Njombe), 134

IGOSI (Njombe), 229

IGULA ( I ring a ), 412

IGUNDU (Musoma), 67

Ikowa settlement (Dodoma), 11

IKWIRIRI (Rufiji ), 331

IMALAMPAKA (Tabora), 154

Inequality; rura 1, 44, 87, 93, 94, 105, 175, 328, 335, 412, 439; see also Peasantry, kulaks

Industries; small scale, $110,123,278,289,333$

Iramba district, 197,248

Iringa district, 91, 92, 241, 249, 255, 404, 411, 412; see a $1 \mathrm{so}$ Is mani division

Iring a region, $64,120,188,242,262,323,324,356,404$

IRUMYA (Mwanza), 263

ISANSA-ITUMPI (Mbozi), 136

ISESA (Mwanza), 151, 437

Ismani division ( Iringa), 90, 93, 94, 105, 208, 250, 381, 411, 412 ITIGA, 182

Itobo ward (Nzega), 159

ITUMBA (Rungwe), 113

ITUNUNU (Serengeti), 229

IWINDI (Mbeya), 272

K

KABUKU-NDANI ( Handeni), 119, 129, 132, 246, 315

Kahama district, 198,229

Kalebezo ward (Geita), 106 


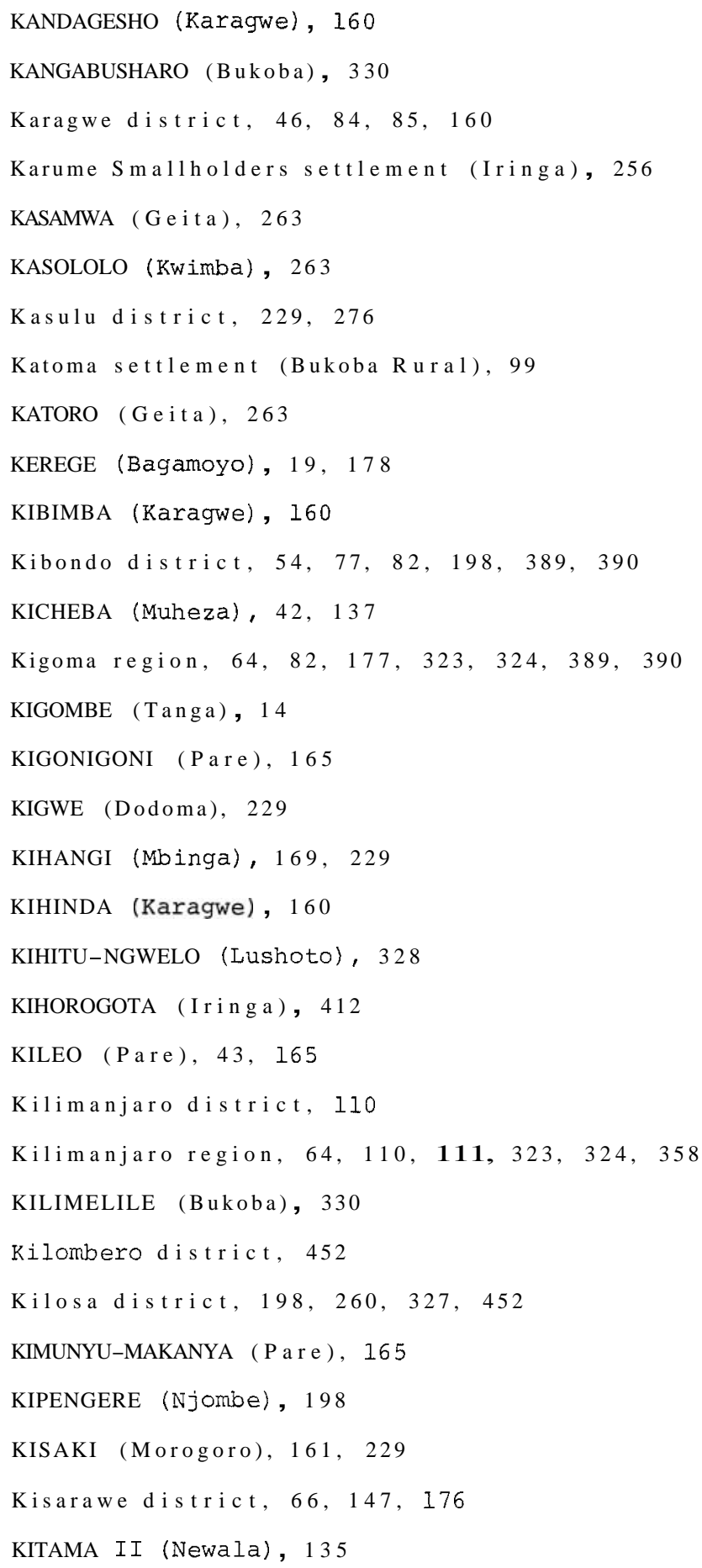


KITUMBI-CHANIKA ( Handeni), 123, 150

KIWANDA (Tanga), 11, 347

KIWERE ( I r ing a ), 256, 359

Kondoa district, $116,128,133,198,362$

Korogwe district, 11, 125, 132, 164, 347

KWAMANGUGU (Handeni), 11, 92, 150

KWAMSISI (Korogwe), 125

KIWANGWA (Bagamoyo), 229

KWEMWEWE (Tanga), 158

Kwimba district, 198,263

Kyela district, 13

$\mathrm{L}$

Land tenure, 21, 62, 84, 85, 93, 106, 243; compensation for property, 53

Laws, 53, 65, 83; see also Villages and Ujamaa Villages Act of 1975

Leadership, $106,273,275,315,318,322$

Lindi district, 198,229

LITOWA ( Songea), 10, 20, 104, 145, 170, 180, 198, 282, 311, 314, 319

LIWETA (Songea), 1, 282

LOTIMA (Moshi), 59

LUGAZE (Bukoba), 330

LUPALE (Rungwe), 276

LUPEMBE (Njombe), 216

Lushoto.district, 3, 50, 132, 153, 155, 181, 231, 328, 374, 417

Lushoto Integrated Development Programme, 50

LWAMI (P a re), 229

LWANZALI (Njombe), 426

LYEHELAGI ( G e i t a ), 229

M

Maasiland: Eng'arukai and Komolonik areas (Masai), 78

MADINGO (Lindi), 229

MAGODA (Njombe), 426 


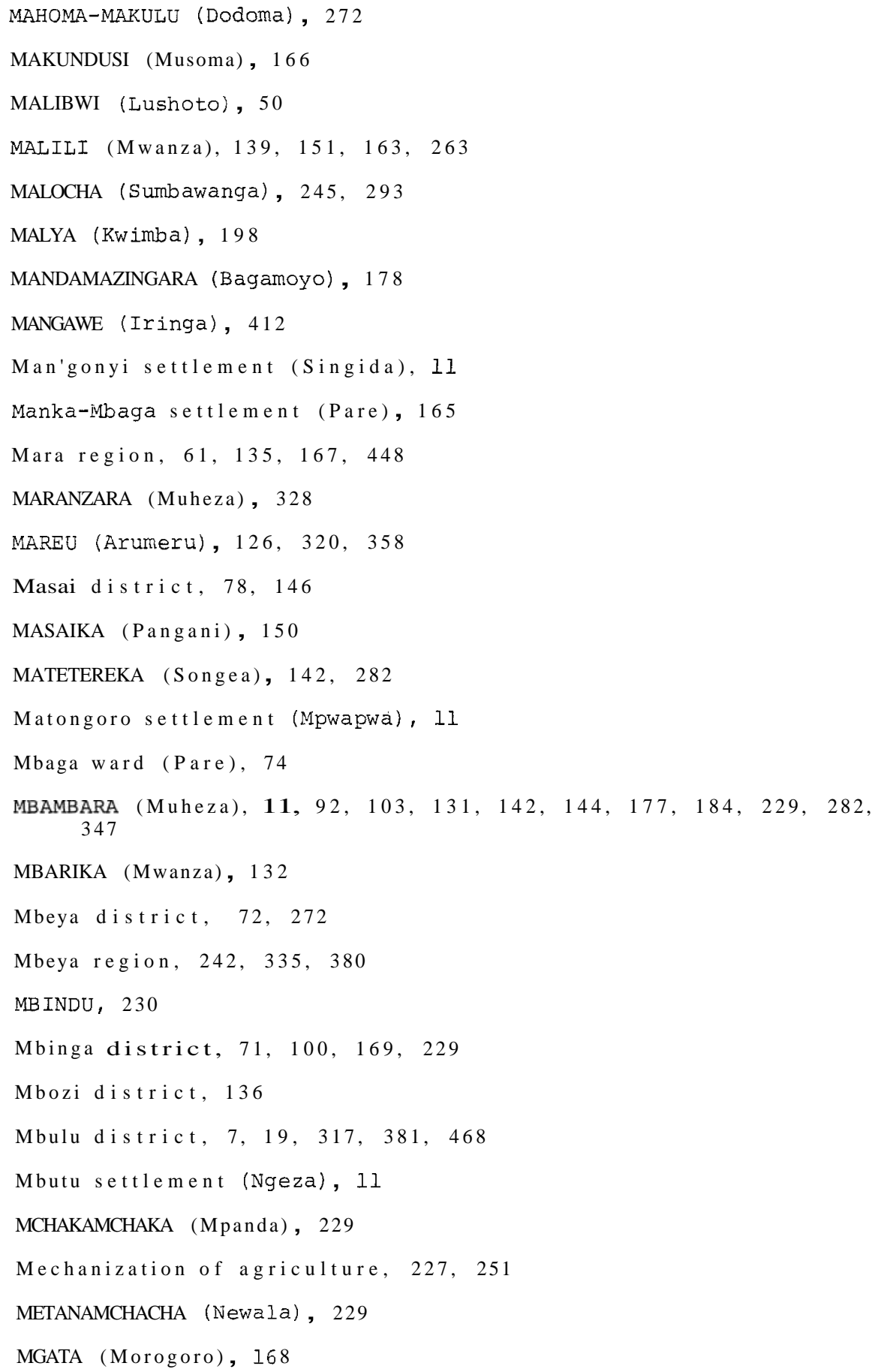


Mgori Dam settlement (Singida), 11

MGWASHI (Lushoto), 328

MINJALE, 198

MIWALENI (Moshi), 59

MKATA (Morogoro), 55

MKINGA LEO (Tanga), 123

MKOKA (Mpwapwa), 320

MKONGO (Rufiji), 152

MKUNGUGU (Iringa), 412

Mlale settlement (Songea), 19

MLESA ( L u s hoto ), 328

MLOWA-BARABARANI (Dodoma), 358

MNG'ARO (Lushoto), 155

Modes of production, 233, 235, 266, 359, 442

MONJO ( L u s hoto), 231

Morogoro district, I, 55, 73, $161,168,229,247,452$

Morogoro region, $124,161,356,388$

Moshi district, 59, $110,156,330$

MOYA MAYOKA ( $\mathrm{H}$ anang), 229, 320

MPANDA (Rungwe), 229

Mpanda district, 198,229

MPUNGUZI (Dodoma), 276

Mpwapwa district, 11, 117, 148, 173, 320. 327

MRIJO CHINI (Kondoa), 198

MSAJE (Handeni), 149

MSANGE (Singida), 229

MSETA (Mpwapwa), 11, $117,320,358$

MSOLWA (ulanga), 161

MSOWERO (Kilosa), 198

MTAKUJA (Moshi), 59, 156,330

MTAKUJA (Mpanda), 198

MTANANA (Mpwapwa), 148, 173 
MTUUNANI (Kisarawe), 147

Mtwara region, 198

Muheza district, 11, 103, 142, 144, 177, 184, 229, 282, 328, 347; see a l so Tanga district

MULEMBULE (Lushoto), 132

Musoma District, 9, 17, 19, 67, 118, 162, 166, 167, 272, 276

MVUMI (Kilosa), 260

MWALO (Kahama), 198

MWAMAKOGE (Kwimba), 263

MWAMASHELE (Shinyanga), 276

MWANGAZA ( B i har a mulo), 229

Mwanza district, 57, 132, 139, 151, 163, 263

Mwanza region, 70, 263, 264

MWONGOSO (Temeke), 272

Mzimzima district, 331

$\mathrm{N}$

NAMIKUNDA (Masai), 146

Nansio Beach (Ukerewe), 254

$\mathrm{N}$ arodism, 442

National Development Corporation, 289

NDOROBONI (Kondoa), 133

Nduli settlement (Iringa), 91, 92

Nduruguni settlement (Handeni), 11

Newala district, 135,229

NGAMU (Singida), 130

$\mathrm{Ngara}$ district, 44,46

NGORONGO (Rufiji), 331

Ngumbo subdivision (Mbinga), 71

NGUNGA (iAwanza), 263

Njombe district , 134, 141, 175, 198, 216, 229, 241, 426

NKAMA (Handeni), 138

NRAMAI (Lushoto), 328 
NKULABI (Dodoma), 276

NKWINI ( $\mathrm{P}$ a re $), 43,165$

North Mara district, 438

NTOBEYE ( Ng a ra ), 44, 46

Nutritional self-sufficiency, 297

NYABIHANGA ( $\mathrm{Ng}$ a r a ), 46

NYAGWIJIMA (Kibondo), 198

Nyakusa, 13

Nyalubere settlement (Geita), 49

NYAMVURA, 198

NYANGUGE (Mwanza), 151

NYAVYUMBU (Kibondo), 54

Nzega district, 11,159

O

OLJORO (Arumeru), 198, 320

OMKAGANDO (Karagwe), 160

OMURUNAZI (Bukoba), 42, 326

Operation Maduka, 104 ; see a lso Shops, communal

Operation Ngodano, 82 ; see also Housing

Operation Vijiji; i n Iringa district, 342; i n Kilimanjarodistrict, 110 ; in Rufiji district, 409, 460; i n Shinyanga district, 70 ; i n Tarime district, 60; i n Coast region, 66; in Dodoma region, $128,362,381$; i n Kigona region, 82, 177, 378, 389, 390; i n Mara region, $61,167,438$; i n West Lake region, 85

Organization $, 6,118,123,151,257,273,275,320,345,353$

$\mathrm{P}$

Pangani district, $123,150,192$

PANYAKOO (T arime), 198

Pare district, 43, 74, 165, 198, 229

Peasantry, $91123,186,327 ;$ Kulaks, 6, 87, 114, 192, 221，312; middle peasants, 442 , see also Villagers

Planning; of villages, $69,81,121,447$; in villages, $123,204,205$, $219,227,279,298,299,313$

Political party leaders, 52, 64, 224; see also Government staff and Rural cadre 
Problems:

In the formation of: $150,347,351,352,354,360,363,448$, 464; economic differentiation, 87, 91; Operation Vijiji, 70, 438; in Bukoba district, 42; in Kibondo district, 54; in Kilimanjaro district, 68; in Morogoro district, 168; in Musoma district, 67; in Rungwe district, 113; in Kilimanjaro region, 62; in Mwanza region, 151; in West Lake region, 76;

In the operation of: 64, 123, 150, 175, 351, 352, 439, 448; accounting, 286; agricultural production, 255, 433

Productive forces; development of, 374

Records: Bookkeeping, 286, 309; Budgeting, 227; Finance, 273

Registration of, 202, 243; see also Villages and Ujamaa Villages Act of 1975

Religion, 288, 292

Rufiji district, 152, 331, 409, 410, 460

RUGAZE (Bukoba), 198, 326

RUGAZI (Nyerere) (Bukoba), 69

RUHITA (Kasulu), 229, 276

Ruiwa settlement (Mbeya), 72

RUKURAIJO (Karagwe), 160

Rungwe district, 13,113, 114, 229, 276

Rural cadre, 58, 230, 360

Rural Savings and Credit Scheme, 310

Rural Training Center, 185, 244

Ruvuma Development Association (RDA), 1, 2, 4, 5, 10, 52, 140, 183, $282,314,353,381$; see also Litowa, Liweta and Matetereka

Rwamkoma settlement (Musoma), 9, 17, 19

SALALA (Iramba), 198

SANGAIWE (Mbulu), 317

SEGERA (Handeni), 11, 123, 132, 172

Serengeti district, 229

SESENGA (Morogoro), 124

Settlements: pre 1967, 1, 4, 8, 15, 24, 64, 98, 243, 296, 378, 396, 456; see also Village Settlement Programme, TANU Youth League Settlements and Ruvuma Development Association 
Shinyanga district, 70,276

SHIRI MATUNDA (MOshi), 59, 110

Shops: Communal, 307, 308; see a 1so Operation Maduka

SINGE (Arusha region), 358

Singida district, $11,130,229$

Social services, $60,283,357,431$

Songea district, 1, 10, 19, 20, 140, 142, 144, 145, 170, 180, 183, $198,282,311,314$

SOTELE B (Kisarawe), 176

STAHABU (Pangani), 123

State farms, 445

Statistics, $51, \quad 295, \quad 397$

Storage: crop, 227,274

Sukumaland, $112, \quad 143, \quad 374$

Sumbawanga district, 245, 293

SUWA, 198

SWAILA (Sumbawanga), 245

TANU Youth League settlements, 4, 5, 16; see also Ruvuma Development A s s ociation

Tabora district, 154,229

Tanga district, $11,14,49,92,123,131,137,150,158$

Tanga region, 95, 123, 174, 198

Tanzania Rural Development Bank, 231，240-242, 252, 260, 261; see a $1 \mathrm{so}$ Credit Tarime district, 60, 198

Technology, 6, 269, 270, 274; see also Mechanization of agriculture

Temeke district, 229, 272

Transport, $227, \quad 236$

TUMBAKOSE (Kondoa), 116

TUMBILINI, 132

$\mathrm{U}$

UBIRI (Lushoto), 181

Ufipa district, $\quad 268$ 
Uhambule set.tlement (Mbeya), 72

Ukerewe district, 254, 322

UKONDAMOYO (Tabora), 229

Ulanga district, 127,161

UPPER KITETE (Mbulu), 7, 19, 381, 468

URORI (MOshi), 59

Usambara, Western; see Lushoto district

Usangu plain (Mbeya), 72, 87

$\mathrm{V}$

Village Management Training Programme, 218, 222; publications of, 227

Village Settlement Programme, 1, 4, 17-19, 21, 23, 29, 64, 333, 350, 353; see also Bwakira Chini, Kabuku-Ndani, Kerege, Mkata, Mlale, Rwamkoma and Upper Kitete Villagers: attitudes of, 64, 72, 242, 323; family characteristics, 175, 263, 264; participation, 320, 326,362 ; women, 46, 316, 329, 330; youth, 331

Villages and Ujamaa Villages Act of 1975, 25, 40, 41, 65, 89, 202, $223,228,408$; see also Laws

Villagization: see Formation of villages/ujamaa villages

W

WALA (Kwimba), 263

WAME (Kahama), 229

WANGAMA (Njombe), 141

Water supply, 312

West Lake region, 45, 46, 76, 84, 85, 179, 224

Witchcraft, 281

Women, see Villagers, women

Z

ZEBA (Lushoto), 328

ZIWA LA DAMU (Mbulu), 317 


\section{B. Author Index}

Anonymous works are indexed according to the journal in which they appear or the institution which published them. Edited works in which several articles about ujamaa villages are found are indexed under the names of the editors only once.

Africa Confidential, 80,466

African Development, 39, 145

Ali, 131

Amani, 271

Andreou, 408

Angwazi, 409, 410

Antoniotto, 332

Apthorpe, 282

Assey, 231

Awiti, 411, 412

B

Babyegeya, 185

Bakula, 42

Balđus, 232, 333

Bamugaya, 116

Banduka, 43

Bango, 149

Barkan, 441

Barker,' 334, 335

Barnes, 260

Barnett, 94

Baum, 336, 337

Bavu, 315

Berry, 11

Binamu, 131

Blue, 413

Boesen, 44, 45, 46, 234

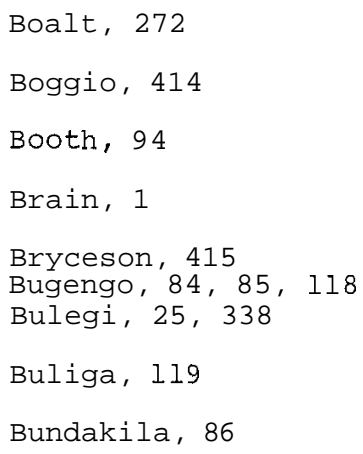

Community Development Trust Fund of Tanzania, 274

Connell, 345

Cooperative Union of Tanganyika, $88,89,206,223,275$

Cordettini, see Cardettini

Coulson, 186, 346, 419

Cunningham, 4, 5, 47, 48, 432 
Dabana, 49, 172

Daily News, 471

Daraja, 347

Davidsson, 236

de Benko, 124

Department of Sociology, 355

Desflosses, 362

Desai, 348

De Vries, 120, 187-189, 195, 349,478

Dorner, 353

Douet, 414

Due, 237-242

Dumont, 6

E

Ellis, 420

Ellman, 7, 350-354

Ergas, 421

Erves, 190

F

Feldman, D., 90-92

Feldman, R., 92-94

First, 422

Fleisher, 481

Fortmann, 120, 316, 356

Free Zanzibar Voice, 418

Freyhold, M., 95, 121-123, 192,

193

Freyhold, K., 191

Fumbuka, 96

G

Gama, 124
Georgulas, 8

Ghai, 357, 358

Giger, 423

Githinji, 125

Godding, 359

Golleth, 126

Gottlieb, 276

Green, 357, 424

Gruhn, 425

Guillotte, 317

Gunza, 9

$\mathrm{H}$

Hansel, 127, 194, 195, 349

Harris, 196

Haulle, 50

Healey, 288

Hess, 360

Hewlett, 361

Hill, 128, 362

Hirst, 51

Honnold, 426

Huizer, 363

Hulls, 199

Hundsdorfer, 479

Hussein, 134

Hyden, 97, 129, 364-366

Ibbott, 10, 52

Inderbitzin, 130

Institut fur Sozialforschung, $233,235,266$ 
Institute of Adult Education, $117,277,293,303$

Inukai , 367

James , 53, 243

J ansen, 483

Jaquement, 130

Jenga, 289, 403

Jobs and Skills Programme for Africa, International Labour Office, 368

Joinet, 427

Juma, 369,428

K

Kabigi, 131

Kaduma, 436

Kaniki, 137

Kathambi, 156

Kahama, C. G., 278

Kahama, K., 132

Kai-Samba， 480

Kajiage, 201

Kajula, 133

Kajumba, see Ndawula-Kajumba

Kampe, 174

Kandege, 134

Kaniki, 137

Karl, 292

Kas ori, 163

Kassami, 184

Kates, 11

Kathambi, 156

Kaunde, 135
Kavura, 54

Kawawa, 12,202

Kayombo, 74, $115,178,200,370$

Kazi, 55

Kazimoto, 56, 279

Kehengu, 136

Keregero, 371

Khan, 357

Kharumo, 203

Kibona, 137

Kikudo, 133

Kikwete, 98

K i m , 372

Kimani, 138

Kimiti, 26

Kimolo, 119

Kindamba, 116

Kinyondo, 99

Kipanga, 147

Ki ro, 244

Kisula, 57

Kiva， 429

Kjekshus, 430

Kocher, 481

Komanya, 373

Konter, 13

Kreutzer, 204

Krokfors, 245

Kuper, 479

Kurschner, 139,431

Kusilawe, 140 
Landberg, 14

Iatham, 297

Latigo, 141

Lawrence, 246, 344

Lee, 357, 358

Lendermann, 423

Levesque, 362

Lewin, 142-144,280, 281,

$318,319,432$

L ofchie, 433, 434

Long, 282

Loxley, 261

Lucas, 157

Luganga, 146

Lukwaro, 296

Lupatu, 247

Luswaga, 370

Lütolf, 423

Luttere11, 58, 344, 417

Lwesya, 136

Lyatuu, 126

Lyimo, 59

Mabele, 204, 252, 372

Machemba, 163

Machunda, 248

Madsen, 46

Maeda, 320, 358, 435, 436

Magatti, 60

Mahecha, 100

Mahimbo, 147
Mahinya, 148

Mahomba, 480

Maina, 149

Majili, 157

Makere, 150

Makere Institute of Social

Research, 11

Mapolu, 96, 151, 374, 437

Mapunda, 27

Markie, 361, 375

Maro, 283

Mascarenhas, $321, \quad 376, \quad 377$

Mashauri, 322

Masheula, 152

Mason, 284

Matalisi, 153

Matango, 61, 438

Mattee, 371

Mauma, 154

Mbakile, 207

Mbenna, 285

Mbilinyi, 439

Mboya, B. J ., 155

Mboya, G. R., 62

Mbwana, 480

McGee, 484

McHenry, 63, 64, 323，324，378， 379

Mchomvu, 156

Mchumo, 65

Mckay, 11, 15

MCKinsey and Company, 440 


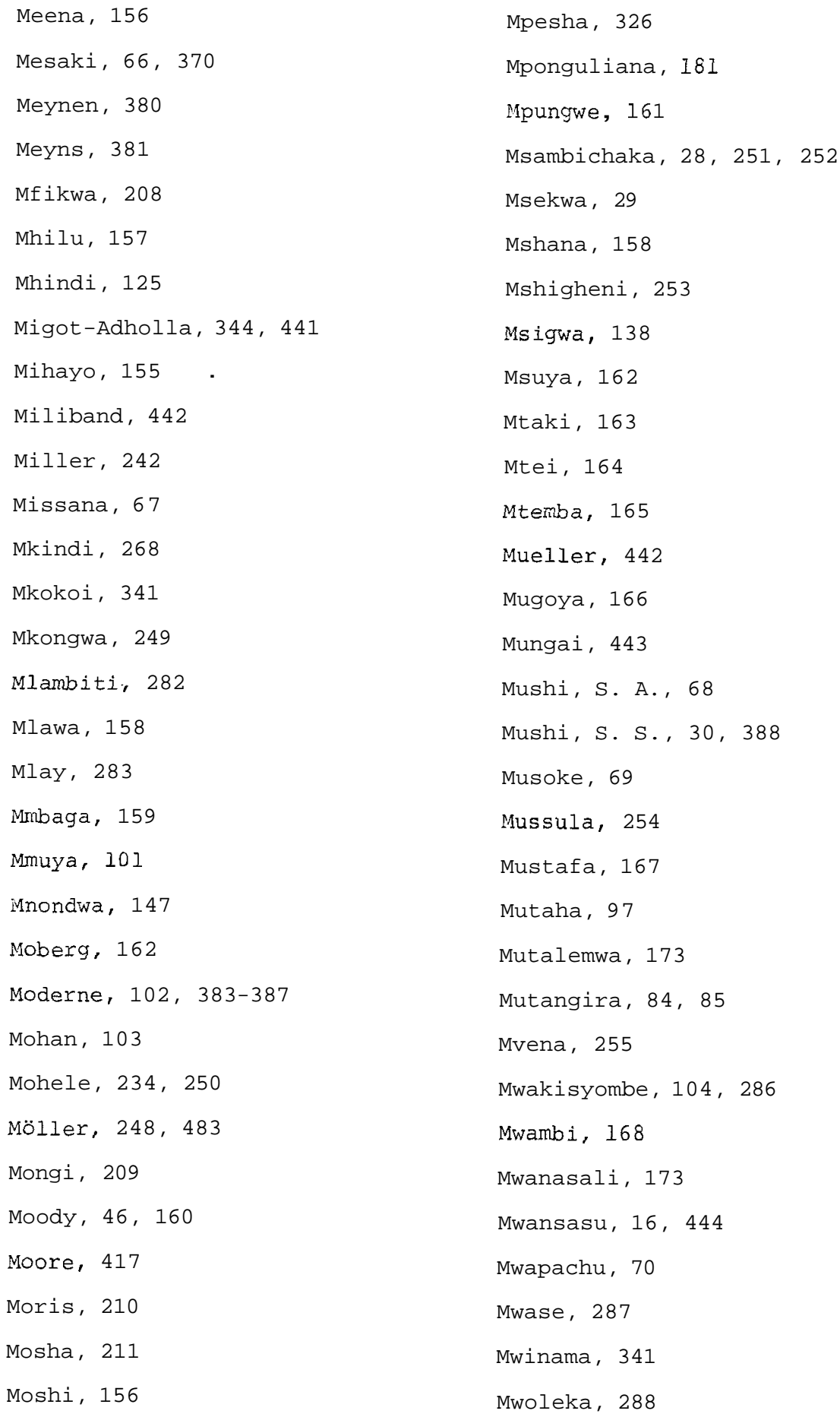


$\mathrm{N}$

Nationalist, 473

Ndawula-Kajumba, 445

Ndedya, 195, 212

Ndissi, 256

Ndomba, 169

Ndonde, 170, 213

Ndulu, 409, 410

Naunguru, C. C., 327

Ndunguru, K. K., 71

Neigus, 214

Nellis, 17

Newiger, 18, 19

Ngalya, 370

Ng'asi, 20

Ngasongwa, 446

Ngeze, 215, 216, 257

Ngotyana, 447

Ngoyani, 171

Ngunangwa, 448

Ng'wandu, 290, 291

Nieuwenhove, 292

Ninivaar, 258

Nindi, 105, 164, 355

Nkhoma, 172

Nsereko, 217

Nshiku. 293

Ntawatawa, 173

Ntirukigwa, 106

Nursey-Bray, 449

Nuwagaba, 184
O

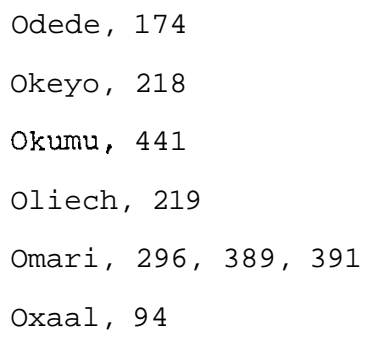

Ruthenberg, 19 
Rwelengera, 85

Rwiza, 211，220

Saibul, 78

Sandberg, 460

Sanga, 222

S au 1, 22, 109, 343，344

S aville, 442

Sawe, 110

Schultz, 393

Schultheis, 372

Schutte, 394

Schweizer, 423

Seidlitz, 461

Sender, 328

Seushi, 261

Sharma, A. C., 262

Sharma, K. L. 408

Sharma, R. D., 263, 264

Shayo, 127

Shengena, 131

Shimba, 300

Sivivji, 462

Smith, A., 323

Smith, L. D., 174

Special correspondent, 79

Standard, 474

Storgaard, 329

Sumra, 265, 484

Sunday news, 475

Svendsen, 395, 432, 463

Swantz, 330, 331
Sweet, 464,465

T

Tamm， 227

TANU, 111, 112, 224, 301, 302, 321,396

Tanzania: Idara ya Mipango ya Utumishi, Wizara ya Maendeleo ya Utumishi,, 304; Kamati ya Kuchungu za Elimu ya Ujamaa na Ushirika, 305; Laws, Statutes, etc., 4-1. Marketing Development Bureau, 225, 226; Ministry of Community Development, 399; National Housing and Building Research Unit Ministry of Lands Housing and Urban Development, 306; Office of the Prime Minister and Second Vice President, 229, 307, 401; Kikundi cha Takwimu, Office of the Prime Minister and Second Vice President, 398; Rural Settlement Commission, 23; Village Management Training Programme, 227; Ujamaa and Cooperative Development Department Office of the Prime Mi$n$ ister and Second Vice President, $40,308-310,397,400$

Tanzania High Court Digest, 221

Tanzania Library Service, 485

$\underline{\text { Tanzania Notes and Records, }} 486$

Teisen, 432

Temu, 24, 467

Thoden Van Velzen, 113, 114

Toroka, 311

Traore, 267

Tschannerl, 312

Tschundi, 402

U

Uhuru, 476

Ujamaa, 197,198

Ujamaa Leo, 470

Ulvund, 268 
University of East Anglia, 404

Urfer, 292, 405

Urio, 131

Ushirika, 477

V

Vai1, 269, 270

Verhagen, 228

Von Freyhold, see Freyhold

Vukovic, 81

Wachiye-Munyasia， 50

Wagao, 82

Wanachuo, Chuo cha COM

(Kivukoni), 230

Waweru, 182

Weaver, 413

Weeks， 406

Welch, 323

Wenner, 183

Westley, 297

Westman, 313

Widstrand, 3

Williams, 83

Wisner, 184

Wolstenholme, 407

Wood, 314

Worsley, 22

Zegge, 468, 469 
The Scandinavian Institute of African Studies in Uppsala was started in 1962 as an element in the initial Scandinavian collaboration to collect and disseminate information about Africa and to promote a scholarly exchange of ideas on topics of central concern to the developing countries.

The Institute's task is to circulate information about Africa to public institutions, private organizations and individual inquirers in the Scandinavian countries. This is done through library and publication work and through educational activities of various kinds.

Research activities. Another of the Institute's principal tasks is to stimulate and support Scandinavian research on Africa. Several research workers are associated with the Institute and travelling scholarships are distributed annually to forward research in Africa.

The library. The library specializes mainly in material on modern Africa. Endeavours are made to stock the current literature on the social sciences, modern history and modern biography. There are complete catalogues, both of the Institute's own book stock and of the stocks of Africana in all the major Scandinavian scientific libraries.

Seminars and courses. Once a year the Institute organizes an international seminar in which specialists from all over the world are assembled for lectures and discussions. The seminar proceedings are published in one of the Institute's publication series.

The Institute also arranges courses for teachers and other persons dealing with information on Africa. Both Scandinavian and non-Scandinavian experts are engaged to lecture on Africa and African problems. In many cases lecture tours are arranged, covering several of the university towns in Scandinavia.

The Institute does not provide any instruction for those aiming at academic degrees.

For more detailed information about the activities of the Institute, we recommend the reading of the annual Newsletter which can be ordered from the Institute free of charge.

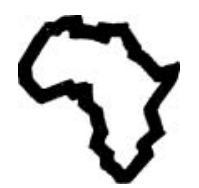

\section{THE SCANDINAVIAN} INSTITUTE OF AFRICAN STUDIES
P. O. Box 2126
S-750 02
UPPSALA, Sweden 